\title{
The Synergistic Beneficial Effect of Thyme Honey and Olive Oil against Diabetes and Its Complications Induced by Alloxan in Wistar Rats
}

\author{
Hajar Lafraxo, Meryem Bakour (D), Hassan Laaroussi, Asmae El Ghouizi ${ }^{D}$, Driss Ousaaid, \\ Abderrazak Aboulghazi, and Badiaa Lyoussi (iD \\ Laboratory of Natural Substances, Pharmacology, Environment, Modeling, Health, and Quality of Life (SNAMOPEQ), \\ Faculty of Sciences Dhar Mehraz, Sidi Mohamed Ben Abdellah University, Fez, Morocco \\ Correspondence should be addressed to Badiaa Lyoussi; lyoussi@gmail.com
}

Received 26 March 2021; Revised 8 August 2021; Accepted 8 September 2021; Published 21 September 2021

Academic Editor: Amir Syahir

Copyright (C) 2021 Hajar Lafraxo et al. This is an open access article distributed under the Creative Commons Attribution License, which permits unrestricted use, distribution, and reproduction in any medium, provided the original work is properly cited.

\begin{abstract}
Diabetes is a metabolic disorder characterized by a chronic increase in blood glucose. Owing to the limitations observed with antidiabetics in modern medicine, medicinal plants and bee products are known as good matrices for the search for new antidiabetic molecules. The present study focused on the evaluation of the hypoglycemic and the protective properties of two natural products widely used in complementary and alternative medicine (thyme honey and olive oil). To achieve this, the study was carried out on Wistar rats rendered diabetic by the injection of a single dose of alloxan monohydrate ( $65 \mathrm{mg} / \mathrm{kg}$ body weight $(B W)$ ). First, the physicochemical characterization and the phytochemical analysis of thyme honey and olive oil were carried out, and then in vivo study was conducted on 42 Wistar rats divided into seven groups: three groups were normal, one group was untreated diabetic, and three groups were diabetic rats treated with thyme honey $(2 \mathrm{~g} / \mathrm{kg} \mathrm{BW})$ or olive oil $(10 \mathrm{~mL} / \mathrm{kg} \mathrm{BW})$ or their combination $((1 \mathrm{~g} / \mathrm{kg} \mathrm{BW}$ of thyme honey) and $(5 \mathrm{~mL} / \mathrm{kg}$ BW of olive oil $))$. During the experiment, the glycemia was measured regularly every 10 days. After 30 days of treatment, the rats were sacrificed. The serum and urine were analyzed to determine hepatic enzymes levels (AST, ALT, ALP, and LDH), lipidic profile (total cholesterol, triglycerides, high-density lipoprotein, lowdensity lipoprotein), and kidney parameters (urea, uric acid, creatinine, total protein, sodium, potassium, and chloride). The liver, pancreas, and kidneys were analyzed to evaluate their histological changes and to determine their enzymatic antioxidant content (catalase, GSH, and GPx) and the levels of MDA. The results obtained showed that thyme honey or olive oil, and especially their combination, improved significantly the blood glucose levels and they protect against metabolic changes and the complications induced by diabetes.
\end{abstract}

\section{Introduction}

Diabetes is a metabolic disease characterized by a chronic increase in blood glucose levels; it occurs when the pancreas does not produce enough insulin due to the autoimmune destruction of $\beta$ cells (type 1 diabetes) or when the body cells become resistant to insulin (type 2 diabetes) [1]. Around the world, the number of people with diabetes continues to increase at an alarming rate. According to Wild et al., the statistics in 2000 was 171 million and it is expected to increase to 366 million diabetes people in 2030 [2]. Diabetes places a heavy burden on diabetic people and their families, as well as on health systems and national economies, due to medical costs, the disease management, as well as the complications which are responsible for significant economic and human losses [3]. The therapeutic strategies of type 1 diabetes are based on the prevention against the destruction of beta cells by autoimmunity, maintaining immune homeostasis, and the restoration of glycometabolic control [4]. Currently, the standard treatment for type 1 diabetes is the lifelong administration of exogenous insulin [5]. The problem that arises is the difficulty to achieve daily blood sugar control, which ultimately leads to the emergence of a large number of serious complications [6]. The pancreas 
or islet transplant remains the most reliable clinical approach to cure type 1 diabetes [7]. This problem prompted researchers to find an alternative solution that could have beneficial effects on the regulation of carbohydrate metabolism and to avoid the side effects of synthetic substances. Natural products used in alternative medicine are among the important axes of research of bioactive molecules that have a hypoglycemic effect [8].

Honey is a natural sweet substance formed by bees from the nectar of flowers or excretions left on plants by sucking insects (honeydew) [9]. There is an innumerable variety of honey, corresponding to the flowers and plants visited by the bees, as well as to the harvested source (nectar or honeydew). Thus, honey was separated into two categories: monofloral honey which comes predominantly from a single floral species (more than $45 \%$ ) and polyfloral honey which results from bees harvesting from several floral species [10]. Generally, honey is composed of $60 \%$ to $85 \%$ of carbohydrates and $12 \%$ to $23 \%$ of water; it also contains enzymes, amino acids, organic acids, vitamins, and phenolic compounds [11].

Traditionally, honey was widely used for wound healing, as a food preservative, and against gastrointestinal illnesses [12]. According to recent literature, honey has revealed the presence of several beneficial effects for human health such as antibacterial [13], antioxidant, anti-inflammatory [14], and cardioprotective effects [15], with potentials as antiobesity [16] and neuroactivation associated with spatial memory [17].

Olive oil is an edible oil obtained from the cultivated varieties of Olea europaea belonging to the Oleaceae family [18]. It is a mixture of chemical compounds; it consists of more than 250 compounds whose saponifiable compounds (triglycerides, saturated, and unsaturated fatty acids) represent $98 \%$ or nonsaponifiable compounds $2 \%$ such as tocopherols (vitamin E), phenolic compounds, and pigments (chlorophylls, carotene) [19]. This composition changes according to the variety and to the pedoclimatic conditions [20].

The benefits of olive oil have been known for a long time; several studies have documented the pharmacological activities of this oil, for instance, antibacterial [21], anti-inflammatory [22], analgesic [23], and anticancer effects [24].

This study aims to evaluate the effect of olive oil and thyme honey as functional products widely used in complementary medicine, on diabetes type 1 induced by alloxan, and also to investigate the possible synergistic therapeutic effect between olive oil and thyme honey against diabetes type 1 and its complications such as dyslipidemia and hepatorenal dysfunction.

\section{Materials and Methods}

2.1. Thyme Honey and Olive Oil Samples. Monofloral thyme honey (Thymus vulgaris. L) and Moroccan Picholine variety of olive oil (Olea europaea. L) were purchased from Sefrou (latitude: $33.8305^{\circ} \mathrm{N}$; longitude: $4.8353^{\circ} \mathrm{W}$; altitude: $850 \mathrm{~m}$; pluviometry: 3 to $14 \mathrm{~mm}$; temperature: 7.7 to $25.6^{\circ} \mathrm{C}$ ). Thyme honey was collected in July 2018 by a professional beekeeper, while olive oil was produced in January 2019 and stored in amber-colored bottles.

In this study, we evaluated the separate and combined effects of thyme honey and olive oil against type 1 diabetes induced by alloxan monohydrate. The choice of these natural products is based on their uses as complementary medicine [25-27].

\subsection{Bioactive Compounds and Free Radical Scavenging Activity}

2.2.1. Polyphenols Content. Polyphenol quantification was determined as follows: $100 \mu \mathrm{l}$ of olive oil or $100 \mu \mathrm{l}$ of thyme honey solution $(5 \mathrm{~g}$ of honey dissolved in $10 \mathrm{ml}$ of distilled water) was mixed with $500 \mu \mathrm{l}$ of Folin-Ciocalteau $(0.2 \mathrm{~N})$ reagent and $400 \mu \mathrm{l}$ of sodium carbonate solution. Gallic acid was used as a standard to achieve the calibration curve; tests were made in triplicate, and the results were expressed as mean $\pm \mathrm{SD}$ in mg gallic acid equivalent per $100 \mathrm{~g}$ sample (GA $\mathrm{mg} / 100 \mathrm{~g})[28,29]$.

2.2.2. Flavonoids Content. Flavonoid quantification was determined as follows: $100 \mu \mathrm{l}$ of olive oil or $100 \mu \mathrm{l}$ of thyme honey solution $(5 \mathrm{~g}$ of honey dissolved in $10 \mathrm{ml}$ of distilled water) were mixed with sodium nitrite (5\%) and $150 \mu \mathrm{l}$ of $\mathrm{AlCl}_{3}$ solution $10 \%, 200 \mu \mathrm{l}$ of $\mathrm{NaOH}(1 \%) 1 \mathrm{M}$ was added after $5 \mathrm{~min}$, and the absorbance was measured at $510 \mathrm{~nm}$. Tests were made in triplicate, and the results were expressed as mean \pm SD. Flavonoid's content values were expressed as in milligrams of quercetin equivalent per 100 grams of the sample (QE mg/100 g) [28, 29].

2.2.3. Content of Thyme Honey in Ascorbic Acid. The content of thyme honey in ascorbic acid was quantified following the titration method described by Nweze et al. Tests were made in triplicate, and the results were expressed as mean $\pm \mathrm{SD}$ in $\mathrm{mg} / 100 \mathrm{~g}$ [30].

2.2.4. Free Radical Scavenging Activity. The method described by Miguel et al. was used for the determination of the DPPH radical scavenging activity [31]. Briefly, $100 \mu$ l of olive oil or $25 \mu \mathrm{l}$ of thyme honey solution ( $5 \mathrm{~g}$ of honey dissolved in $10 \mathrm{ml}$ of distilled water) were mixed with $875 \mu \mathrm{l}$ of DPPH solution $(63.4 \mu \mathrm{M})$. The absorbance was read at $517 \mathrm{~nm}$, and the antiradical activity was estimated based on the percentage of DPPH radical scavenged using the following formula:

$$
\mathrm{IC} 50 \%=\left[\frac{(\text { control absorbance }- \text { sample absorbance })}{\text { control absorbance }}\right] \times 100 .
$$

Tests were made in triplicate, and the results were expressed as mean $\pm \mathrm{SD}$ in $\mathrm{mg} / \mathrm{ml}$.

2.3. Phenolics Compounds Identification and Quantification in Olive Oil and Thyme Honey. The analysis of the 
polyphenols in the olive oil sample was carried out on a SHIMADZU PROMINENCE HPLC system fitted with a DAD detector, a degasser, and an LC A20 type pump as well as an RYODINE type manual injector. The separation by HPLC of the polyphenols was carried out on an Agilent Zorbax C18 column dimension $4.6 \mathrm{~mm} \times 250 \mathrm{~mm} 5 \mathrm{um}$ $100 \mathrm{~A}$ at A flow rate of $1 \mathrm{ml} / \mathrm{min}$ of a ternary mobile phase of acetonitrile, methanol, and water; column temperature was $30^{\circ} \mathrm{C}$; and the injection volume was $20 \mu \mathrm{l}$. Under the same conditions, syringic acid and Tyrosol standard solutions were injected to determine the response factor [32]. The phenolic compounds in thyme honey have been analyzed previously [33].

2.4. Mineral Content in Thyme Honey and Olive Oil. Mineral contents in thyme honey and olive oil were analyzed by the calcination method using ICP-AES, following the method described by Silva et al. Briefly, $5 \mathrm{ml}$ of nitric acid $0.1 \mathrm{M}$ were added to the ashes of honey and olive oil. Then, $10 \mathrm{ml}$ of the same acid was added, and the mixture was made up to $25 \mathrm{ml}$ with ultrapure water; mineral elements were determined using an air/acetylene flame, and the quantitative determination was carried out after calibrating the instrument using ranges of calibrations of $\mathrm{Na}, \mathrm{K}, \mathrm{Ca}, \mathrm{Mg}, \mathrm{Fe}$, $\mathrm{Cu}, \mathrm{Zn}, \mathrm{Ni}, \mathrm{Cd}$, and $\mathrm{Pb}$ dissolved in $0.1 \%$ lanthanum. All samples were analyzed in triplicate [34].

\subsection{Physicochemical Analysis of Thyme Honey}

2.5.1. Electrical Conductivity. Twenty grams of thyme honey was dissolved in $100 \mathrm{ml}$ of distilled water, and then the electrical conductivity was measured at $20^{\circ} \mathrm{C}$ using an electrical conductivity cell [35].

2.5.2. $p H$. Ten grams of thyme honey was dissolved in $100 \mathrm{ml}$ of ultrapure water using a $\mathrm{pH}$ meter [35].

2.5.3. Free Acidity and Lactone Acidity. Free acidity assay was determined as follows: $1 \mathrm{~g}$ of thyme honey was dissolved in $25 \mathrm{ml}$ of ultrapure water and a solution of $\mathrm{NaOH} 0.05 \mathrm{M}$ up to the equivalence point $(\mathrm{pHe}=8.3)$. Lactone acidity was obtained by the addition of $1 \mathrm{ml}$ of $\mathrm{NaOH} 0.05 \mathrm{M}$ followed by titration with $\mathrm{HCl} 0.05$ to return to the equivalence point [35].

2.5.4. Ash Content. The ash content was obtained by ashing $5 \mathrm{~g}$ of thyme honey at $600^{\circ} \mathrm{C}$, and then the weight of ash was measured [35].

2.5.5. Moisture and Total Soluble Solids (TSSs). The refractometer was used for moisture and total soluble solids analysis [29].

2.5.6. Diastase Activity. Diastase activity was analyzed as described by Bogdanov and then calculated using formula (1): diastase number $=300 / T x$. Tx is the time taken by the reaction for the absorbance of the blue color to decrease to approximately 0.235 [35].

2.5.7. Thyme Honey Color. Ten grams of honey was dissolved in $20 \mathrm{ml}$ of distilled water; then the absorbance was measured at $635 \mathrm{~nm}$ using a spectrophotometer. The $\mathrm{mm}$ Pfund values were obtained using the following formula [36]:

$$
m m \text { Pfund }=-38.7+371.39 \times \text { absorbances } .
$$

2.5.8. Melanoidins Content. Melanoidins content was estimated based on the browning index by measuring the net absorbance of thyme honey at $450 \mathrm{~nm}$ and $720 \mathrm{~nm}$ (net absorbance $=$ A450 - A720) [37].

\subsection{Physicochemical Analysis of Olive Oil}

2.6.1. Free Acidity. The free acidity, expressed as a percentage of oleic acid, was determined by dissolving $1 \mathrm{~g}$ of olive oil in a diethyl ether/ethylic alcohol solution $1: 1$. The mixture was titrated with a $0.1 \mathrm{~N} \mathrm{NaOH}$ solution [38].

2.6.2. Peroxide Index. One gram of olive oil was dissolved in $12.2 \mathrm{ml}$ of the acid mixture acetic/chloroform $3: 2(\mathrm{v} / \mathrm{v})$. The mixture obtained was titrated with a $0.01 \mathrm{~N}$ sodium thiosulfate solution [38].

2.6.3. Specific Extinction Coefficient at $232 \mathrm{~nm}$ and $270 \mathrm{~nm}$. The specific extinction coefficient at $232 \mathrm{~nm}$ and $270 \mathrm{~nm}$ was determined according to the protocol described by the official analytical methods in EC Regulation 2568/91 [39].

2.6.4. Chlorophyll Content. Here, $7.5 \mathrm{~g}$ of olive oil was dissolved in cyclohexane and taken to a final volume of $25 \mathrm{ml}$. The absorbance of the mixture was determined at $470 \mathrm{~nm}$, the extinction coefficient applied was $E_{0}=613$, and chlorophyll content was calculated using the following formula:

$$
\text { chlorophyll content }=\frac{(A 670 \times 106)}{(613 \times 100 \times d)},
$$

$A$ is the absorbance, and $d$ is the spectrophotometer cell thickness $(1 \mathrm{~cm})$. The tests were made in triplicate, and the results were expressed as mean $\pm \mathrm{SD}$ in $\mathrm{mg} / \mathrm{kg}$ [40].

2.6.5. Carotenoids Content in Olive Oil. Here, $7.5 \mathrm{~g}$ of olive oil was dissolved in cyclohexane and taken to a final volume of $25 \mathrm{ml}$. The absorbance of the mixture was determined at $470 \mathrm{~nm}$, the extinction coefficient applied was $E_{0}=2000$, and the carotenoids content was calculated using the following formula:

$$
\text { carotenoids content }=\frac{(A 470 \times 106)}{(2000 \times 100 \times d)},
$$


$A$ is the absorbance, and $d$ is the spectrophotometer cell thickness $(1 \mathrm{~cm})$. The tests were made in triplicate, and the results were expressed as mean $\pm \mathrm{SD}$ in $\mathrm{mg} / \mathrm{kg}$ [40].

\subsection{Induction of Diabetes Mellitus and Experimental Design}

2.7.1. Ethical Approval. The ethical approval was obtained from Sidi Mohamed Ben Abdellah University in Fez under the responsibility of the Laboratory of Natural Substances, Pharmacology, Environment, Modeling, Health, and Quality of life (SNAMOPEQ), Department of Biology, Faculty of Sciences Dhar EL Mahraz of Fez, Morocco (L.20.USMBA-SNAMOPEQ 2017-03). The care and handling of the animals were following the internationally accepted standard guidelines for the Care and Use of Laboratory Animals, and the protocol was approved by our institutional committee on animal care, University Sidi Mohamed Ben Abdellah, Faculty of Sciences Dhar EL Mahraz Fez, Morocco.

2.7.2. Diabetes Induction. A total of 42 rats with $190.85 \pm 5.14 \mathrm{~g}$ of body weight (BW) were randomly divided into 7 groups, with 6 rats in each group. The animals were housed in a standard environmental condition $\left(23 \pm 3^{\circ} \mathrm{C}\right.$ with $12 \mathrm{~h}$ light/dark cycles) and fed with standard rodent chow and water ad libitum. Diabetes mellitus was induced in overnight fasted healthy male Wistar rats by a single intravenous injection of alloxan monohydrate $(65 \mathrm{mg} / \mathrm{kg} \mathrm{BW})$ prepared in normal saline. After $72 \mathrm{~h}$ of alloxan injection, only rats with glycemia $\geq 250 \mathrm{mg} / \mathrm{dl}$ were considered diabetics and used in this study.

The experimental protocol was carried out as follows:

Group1 (DW): six healthy rats (nondiabetic) received distilled water $(10 \mathrm{ml} / \mathrm{kg} \mathrm{BW})$

Group2 (TH): six healthy rats (nondiabetic) received thyme honey $(2 \mathrm{~g} / \mathrm{kg} \mathrm{BW})$

Group3 (OO): six healthy rats (nondiabetic) received olive oil $(10 \mathrm{ml} / \mathrm{kg} \mathrm{BW})$

Group4 (DC + DW): six diabetic rats were treated with distilled water $(10 \mathrm{ml} / \mathrm{kg} \mathrm{BW})$

Group5 $(\mathrm{DC}+\mathrm{TH})$ : six diabetic rats were treated with thyme honey $(2 \mathrm{~g} / \mathrm{kg} \mathrm{BW})$

Group6 (DC + OO): six diabetic rats were treated with olive oil $(10 \mathrm{ml} / \mathrm{kg} \mathrm{BW})$

Group7 $(\mathrm{DC}+\mathrm{TH}+\mathrm{OO})$ : six diabetic rats were treated with a combination of thyme honey $(1 \mathrm{~g} / \mathrm{kg} \mathrm{BW})$ and olive oil $(5 \mathrm{ml} / \mathrm{kg} \mathrm{BW})$

All treatments were given orally every day for 30 days; the rats were weighed every ten days. At the end of the experiment, the urine of each rat was collected and the blood was taken under diethyl ether anesthesia by retro-orbital bleeding, the samples were separated by centrifugation $(2000 \times \mathrm{g})$ for $10 \mathrm{~min}$.
2.7.3. Biochemical Analysis. Serum samples were analyzed for blood fasting glucose, hepatic enzymes (aspartate aminotransferases (AST), alanine aminotransferases (ALT), alkaline phosphatase (ALP), lactate dehydrogenase (LDH)), lipidic profile (total cholesterol (TC), triglycerides (TG), high-density lipoprotein (HDL-C), low-density lipoprotein (LDL-C)), and kidney parameters (urea, uric acid, creatinine, total protein, sodium $\left(\mathrm{Na}^{+}\right)$, potassium $\left(\mathrm{K}^{+}\right)$, chloride $\left.\left(\mathrm{Cl}^{-}\right)\right)$.

Urine samples were analyzed for uric acid, creatinine, total protein, sodium $\left(\mathrm{Na}^{+}\right)$, potassium $\left(\mathrm{K}^{+}\right)$, and chloride $\left(\mathrm{Cl}^{-}\right)$.

2.7.4. Catalase and Glutathione Peroxidase Activity in the Pancreas, Liver, and Kidneys of Normal and Diabetic Rats. Catalase (CAT) activity was calculated according to the method described by Aebi et al. [41]. A decrease in absorbance due to $\mathrm{H}_{2} \mathrm{O}_{2}$ degradation was monitored spectrophotometrically at $240 \mathrm{~nm}$ for $1 \mathrm{~min}$, and the activity was expressed as $\mu \mathrm{mol} \mathrm{H}_{2} \mathrm{O}_{2} / \mathrm{min} / \mathrm{mg}$ protein. Glutathione peroxidase $(\mathrm{GPx})$ activity was estimated according to the method of Flohé [42]. The activity was expressed as moles of GSH oxidized/min/mg protein.

2.7.5. Reduced Glutathione (GSH) Levels in the Pancreas, Liver, and Kidneys of Normal and Diabetic Rats. GSH levels were measured following the protocol described by Ellman [43]. Briefly, $3 \mathrm{~mL}$ of sulfosalicylic acid (4\%) was added to $500 \mathrm{~mL}$ of the homogenate liver, pancreas, and kidney tissues. The mixture was centrifuged at $2,500 \times \mathrm{g}$ for $15 \mathrm{~min}$, and then prepared Ellman's reagent was added to $500 \mathrm{~mL}$ of supernatant. The absorbance was measured at $412 \mathrm{~nm}$ after $10 \mathrm{~min}$. The total GSH content was expressed as $\mu \mathrm{g} / \mathrm{g}$ of tissue.

2.7.6. Lipid Peroxidation (MDA) Levels in the Pancreas, Liver, and Kidneys of Normal and Diabetic Rats. The formation of products of lipid peroxidation was quantified in the liver, pancreas, and kidney tissues using the thiobarbituric acid-reactive substances (TBARSs) method, as reported previously by Kassan [44], and absorbance was measured at $532 \mathrm{~nm}$. Results were expressed as malondialdehyde (MDA) concentration (nmol/g tissue).

2.7.7. Histological Analysis. Histological analysis of the liver, pancreas, and kidney was performed using the method described by Bakour et al. [28]. The organs were fixed in the formalin solution (10\%) for $24 \mathrm{~h}$, and then tissue samples were dehydrated using ethanol with a series of increasing concentrations. The organs were next clarified in toluene and then embedded in paraffin. A microtome was used to cut fine sections (5-6 mm) from paraffin blocks. Hematoxylin and Eosin (H\&E) were used for staining the slides obtained for observation under an optical microscope. 
2.8. Statistical Analysis. Statistical comparisons between the groups were performed with one-way analysis of variance (ANOVA) followed by the Tukey test, and the comparison between rat BWs was made by $t$-test using GraphPad Prism (®) software (version 5.0; GraphPad Software, Inc., San Diego, USA). Data were represented as mean $\pm \mathrm{SD} \quad\left({ }^{*} p<0.05\right.$, ${ }^{* *} p<0.01$, and $\left.{ }^{* * *} p<0.001\right)$.

\section{Results and Discussion}

3.1. Bioactive Compounds and Free Radical Scavenging Activity. Antioxidants are bioactive molecules present in food in varying concentrations; they protect the body's cells against the harmful effects of free radicals, and they prevent the organism from several diseases [45]. There is compelling evidence that consuming foods rich in antioxidants like polyphenols, flavonoids, and vitamins is strongly associated with good health and functional longevity [46]. In the present study, the antioxidant content in thyme honey and olive oil was analyzed, and the results revealed that thyme honey contains a high concentration of antioxidant compounds (polyphenols: 192.82 $\pm 15.24 \mathrm{GA} \cdot \mathrm{mg} / 100 \mathrm{~g}$; flavonoids: $11.59 \pm 0.20$ QE.mg/100 $\mathrm{g}$ and ascorbic acid: $13.16 \pm 1.22 \mathrm{mg} / 100 \mathrm{~g})$, as well as a good free radical scavenging activity $\left(\mathrm{IC}_{50}=15.37 \pm 0.97 \mathrm{mg} / \mathrm{ml}\right.$ ) (Table 1$)$. These results are in the range of those found by Laaroussi et al. for eight samples of Bupleurum spinosum honey [29] and almost similar to the findings obtained by Bouhlali et al for Moroccan thyme honey with a polyphenol content of $113.853 \pm 1.103 \mathrm{GA} \cdot \mathrm{mg} / 100 \mathrm{~g}$ and flavonoids content of $17.908 \pm 0.137$ rutin equivalents $\mathrm{mg} / 100 \mathrm{~g}$ [47]. The antioxidant activity of the studied thyme honey was evaluated using the DPPH free radical scavenging activity, and the concentration of thyme honey required to scavenge $50 \%$ of $\mathrm{DPPH}$ free radicals was $\left(\mathrm{IC}_{50}=15.37 \pm 0.97 \mathrm{mg} / \mathrm{ml}\right)$. The antioxidant activity of honey is highly related to the floral source and the pedoclimatic conditions [48].

In vitro tests of olive oil showed a content of $33.48 \pm 1.54 \mathrm{GA} \cdot \mathrm{mg} / 100 \mathrm{~g}$ in polyphenols and $16.03 \pm 0.56 \mathrm{QE}$ $\mathrm{mg} / 100 \mathrm{~g}$ in flavonoids. The results of the DPPH test showed an $\mathrm{IC}_{50}$ value of $2.74 \pm 0.12 \mathrm{mg} / \mathrm{mL}$ (Table 1 ). These results were better than those obtained by Negro et al. for eight genotypes/ cultivars from Italy (Colozzese, Barone di Monteprofico, Cellina di Nardò, Cornola, Ogliarola di Lecce, Orniella, Oliva Grossa, Spina) [49]. Several factors can influence the content of phenolic compounds in olive oil, such as olive maturation, seasonal variation, environmental factors, the intravarietal diversity of the olive tree, and the method of extraction. The rich composition of our sample studied in polyphenols revealed that the olive oil studied did not undergo any heating and it was stored and handled in very good condition. These compounds, like the other minor constituents of olive oil, contribute to sensory and organoleptic properties and the prevention of oil auto-oxidation [50].

3.2. Antioxidant Compounds Identification and Quantification in Olive Oil. Different classes of antioxidants are present in olive oil such as phenolic alcohols, phenolic acids, secoiridoids and derivatives, hydroxycinnamic acid derivatives, flavonoids, triterpenic acids, and tocopherols [51]. The sensory properties and health benefits of olive oil are strongly linked to its volatile and phenolic composition [52]. Certain compounds, such as oleuropein, give olive oil a bitter flavor and a pungent sensation [53]. The analysis of antioxidant compounds found in our studied olive oil is presented in Table 2 and revealed that the predominant compound is oleacin $(253.80 \pm 1.52 \mathrm{mg} / \mathrm{kg})$, followed by tyrosol (67.04 $\pm 1.12 \mathrm{mg} / \mathrm{kg})$, hydroxytyrosol $(36 \pm 1 \mathrm{mg} / \mathrm{kg})$, apigenin $(31 \pm 1 \mathrm{mg} / \mathrm{kg})$, and syringic acid $(15 \pm 1 \mathrm{mg} / \mathrm{kg})$. The lowest concentrations showed by luteolin, oleuropein, and cinnamic acid are $7.20 \pm 0.14 \mathrm{mg} / \mathrm{kg}, 4.86 \pm 0.63 \mathrm{mg} / \mathrm{kg}$, and $3.35 \pm 0.11 \mathrm{mg} / \mathrm{kg}$, respectively. The secoiridoids present in olive oil are derived mainly from oleuropein by enzymatic hydrolysis carried out by the $\beta$ glucosidase enzyme [54].

3.3. Mineral Content in Thyme Honey and Olive Oil. Macroelements and microelements play an essential role in the metabolism and physiological functions of the organism. Adequate levels of mineral elements are essential to cope with the metabolic responses linked to the pathological situation. Micronutrients such as minerals are provided mainly by foods [55]. The results of mineral analysis of thyme honey and olive oil studied showed that the content in macroelements in both samples was in the following order: the major element was sodium $(954.24 \pm 0.20 \mathrm{mg} / \mathrm{kg}$ in olive oil and $1012.32 \pm 0.12 \mathrm{mg} / \mathrm{kg}$ in thyme honey) followed by potassium $(405.94 \pm 0.30 \mathrm{mg} / \mathrm{kg}$ in olive oil and $752.63 \pm 0.52 \mathrm{mg} / \mathrm{kg}$ in thyme honey), calcium $(204.05 \pm 1.12 \mathrm{mg} / \mathrm{kg}$ in olive oil and $124.28 \pm 0.18 \mathrm{mg} / \mathrm{kg}$ in thyme honey), magnesium $(172.90 \pm 1.63 \mathrm{mg} / \mathrm{kg}$ in olive oil and $85.31 \pm 0.59$ in thyme honey), and iron $(13.269 \pm 0.86 \mathrm{mg} / \mathrm{kg}$ in olive oil and $1.58 \pm 0.52 \mathrm{mg} / \mathrm{kg}$ in thyme honey). Similarly, for microelements, the major metals were zinc in thyme honey and olive oil with concentrations $7.98 \pm 0.45 \mathrm{mg} / \mathrm{kg}$ and $5.0614 \pm 0.52 \mathrm{mg} / \mathrm{kg}$, respectively, followed by copper and nickel (Table 3). However, heavy metals like cadmium and lead are present in acceptable concentrations [56].

\subsection{Physicochemical Parameters of Thyme Honey and Olive Oil}

3.4.1. Physicochemical Parameters of Thyme Honey. Physicochemical analyses of thyme honey are presented in Table 4. The honey analyzed in our study is acidic with a $\mathrm{pH}$ value of 4 , which is in the range of Codex Alimentarius Commission standards [57]; the acidity of honey is due to its organic acid content [58].

Acidity is an important criterion of the quality of honey; the studied sample revealed a free acidity of $28.56 \pm 1.54 \mathrm{meq} /$ $\mathrm{kg}$ and a lactonic acidity of $9.13 \pm 0.18 \mathrm{mEq} / \mathrm{kg}$, with the total acidity value of $37.69 \pm 1.46 \mathrm{meq} / \mathrm{kg}$. These results are in line with those indicated by the Codex Alimentarius [57]. This indicates an absence of fermentation and the freshness of the studied honey. 
TABLE 1: Bioactive compounds and free radical scavenging activity of thyme honey and olive oil.

\begin{tabular}{lcccc}
\hline & Polyphenols GA.mg/100 g & Flavonoids QE·mg $/ 100 \mathrm{~g}$ & Ascorbic acid $(\mathrm{mg} / 100 \mathrm{~g})$ & $\mathrm{DPPH}\left(\mathrm{IC} \mathrm{F}_{50}=\mathrm{mg} / \mathrm{mL}\right)$ \\
\hline Thyme honey & $192.82 \pm 15.24$ & $11.59 \pm 0.20$ & $13.16 \pm 1.22$ & $15.37 \pm 0.97$ \\
Olive oil & $33.48 \pm 1.54$ & $16.03 \pm 0.56$ & - & $2.74 \pm 0.12$ \\
\hline
\end{tabular}

TABle 2: Phenolic compounds identification and quantification in olive oil.

\begin{tabular}{lr}
\hline Phenolic compounds & Concentration $(\mathrm{mg} / \mathrm{kg})$ \\
\hline Hydroxytyrosol & $36 \pm 1$ \\
Tyrosol & $67.04 \pm 1.12$ \\
Syringic acid & $15 \pm 1$ \\
Oleuropein & $4.89 \pm 0.63$ \\
Oleacein & $253.80 \pm 1.52$ \\
Pinoresinol & $24.04 \pm 0.21$ \\
Cinnamic acid & $3.351 \pm 0.11$ \\
Luteolin & $7.20 \pm 0.14$ \\
Apigenin & $31 \pm 1$ \\
Total & $442.321 \pm 6.73$ \\
\hline
\end{tabular}

TABLE 3: Minerals content in thyme honey and olive oil.

\begin{tabular}{|c|c|c|c|c|c|}
\hline Sample & & & linerals $(\mathrm{mg} / \mathrm{k}$ & & \\
\hline Olive oil & $\begin{array}{c}\mathrm{Na} \\
954.24 \pm 0.20 \\
\mathrm{Cu} \\
0.438 \pm 0.09\end{array}$ & $\begin{array}{c}\mathrm{K} \\
405.94 \pm 0.30 \\
\mathrm{Zn} \\
5.0614 \pm 0.52\end{array}$ & $\begin{array}{c}\mathrm{Ca} \\
204.05 \pm 1.12 \\
\mathrm{Ni} \\
0.2357 \pm 0.15\end{array}$ & $\begin{array}{c}\mathrm{Mg} \\
172.90 \pm 1.63 \\
\mathrm{Cd} \\
0.0903 \pm 0.011\end{array}$ & $\begin{array}{c}\mathrm{Fe} \\
13.269 \pm 0.86 \\
\mathrm{~Pb} \\
\mathrm{ND}\end{array}$ \\
\hline Thyme honey & $\begin{array}{c}\mathrm{Na} \\
1012.32 \pm 0.12 \\
\mathrm{Cu} \\
0.827 \pm 0.124\end{array}$ & $\begin{array}{c}\mathrm{K} \\
752.63 \pm 0.52 \\
\mathrm{Zn} \\
7.98 \pm 0.45\end{array}$ & $\begin{array}{c}\mathrm{Ca} \\
124.28 \pm 0.18 \\
\mathrm{Ni} \\
0.087 \pm 0.012\end{array}$ & $\begin{array}{c}\mathrm{Mg} \\
85.31 \pm 0.59 \\
\mathrm{Cd} \\
0.047 \pm 0.004\end{array}$ & $\begin{array}{c}\mathrm{Fe} \\
1.58 \pm 0.52 \\
\mathrm{~Pb} \\
0.017 \pm 0.01\end{array}$ \\
\hline
\end{tabular}

TABle 4: Physicochemical analysis of thyme honey and olive oil.

\begin{tabular}{|c|c|c|c|c|c|c|}
\hline & \multicolumn{6}{|c|}{ Physicochemical analysis } \\
\hline \multirow{4}{*}{$\begin{array}{l}\text { Thyme } \\
\text { honey }\end{array}$} & $\mathrm{pH}$ & Free acidity (mEq/kg) & $\begin{array}{l}\text { Lactonic acidity } \\
(\mathrm{mEq} / \mathrm{kg})\end{array}$ & $\begin{array}{l}\text { Total acidity } \\
(\mathrm{mEq} / \mathrm{kg})\end{array}$ & Moisture (\%) & Ash content (\%) \\
\hline & $4.0 \pm 0.05$ & $28.56 \pm 1.54$ & $9.13 \pm 0.18$ & $37.69 \pm 1.46$ & $19.0 \pm 0.04$ & $0.27 \pm 0.00$ \\
\hline & $\begin{array}{l}\text { Electrical conductivity } \\
(\mathrm{mS} / \mathrm{cm})\end{array}$ & $\begin{array}{l}\text { Diastasic activity } \\
\text { (shading units/g) }\end{array}$ & TSS (\%) & Pfund scale (mm) & Honey color & Melanoidins \\
\hline & $462 \pm 5.12$ & $15.43 \pm 2.03$ & $81.0 \pm 0.21$ & $121.74 \pm 5.43$ & Amber & $0.83 \pm 0.07$ \\
\hline \multirow[t]{2}{*}{ Olive oil } & Free acidity $\%$ & $\begin{array}{l}\text { Peroxide index mEq } \\
\mathrm{O}_{2} / \mathrm{kg}\end{array}$ & K232 & $\mathrm{K} 270$ & $\begin{array}{l}\text { Chlorophyll } \\
\text { (mg/kg) }\end{array}$ & $\begin{array}{l}\text { Carotenoids } \\
(\mathrm{mg} / \mathrm{kg})\end{array}$ \\
\hline & $0.56 \pm 0.01$ & $4.6 \pm 0.04$ & $0.08 \pm 0.00$ & $0.21 \pm 0.00$ & $14.55 \pm 1.02$ & $6.2 \pm 0.7$ \\
\hline
\end{tabular}

The determination of water content (moisture) in honey allowed us to know the handling conditions of honey by beekeepers, such as storage, fermentation of honey, climate, and extraction conditions [29]. The analysis result shows that the water content of our sample is $19.0 \pm 0.04 \%$ which remains below the maximum threshold recommended (20\%) by the Codex Alimentarius [57].

The determination of the electrical conductivity and the ash content in honey allowed us to know the botanical origin of honey (monofloral or multifloral) and the mineral content of nectar [35]. Examination of the results of our sample shows that the electrical conductivity has a value of $462 \mu \mathrm{S}$ / $\mathrm{cm}$, which is below the limit set by the Codex Alimentarius and EU Council $(800 \mu \mathrm{S} / \mathrm{cm})[57,59]$.

The color allows the classification of different kinds of honey according to the Pfund index. Our sample has a Pfund index of $121.74 \pm 5.43 \mathrm{~mm}$, and it is classified as a dark "Amber" color. Melanoidins are polymeric structures formed when sugar and amino acids combine as a result of the Maillard reaction; melanoidins analysis in thyme honey shows content of $0.83 \pm 0.07$. These results are in line with the recommended values cited by the United States Standards for Grades of Extracted Honey (USDA) [60]. 
TABLE 5: Effect of daily oral administration of thyme honey, olive oil, and their combination on blood glucose level in the diabetic and nondiabetic rats.

\begin{tabular}{|c|c|c|c|c|}
\hline \multirow{2}{*}{ Experimental groups } & \multicolumn{4}{|c|}{ Blood fasting glucose levels (mg/dl) } \\
\hline & Day 0 (baseline) & Day 10 & Day 20 & Day 30 \\
\hline DW & $101 \pm 4.24$ & $97 \pm 2.82$ & $98.5 \pm 4.94$ & $102.5 \pm 4.94^{\neq \neq \neq c}$ \\
\hline $\mathrm{OO}$ & $95.5 \pm 6.36$ & $96 \pm 1.41$ & $98 \pm 5.65$ & $97 \pm 7.07^{\neq \neq \neq c}$ \\
\hline $\mathrm{TH}$ & $98 \pm 2.82$ & $99 \pm 1.56$ & $100 \pm 1.12$ & $98 \pm 4.59^{\neq \neq \neq c}$ \\
\hline DC & $351.5 \pm 27.57$ & $399.5 \pm 16.26^{* * a}$ & $417,5 \pm 13.43^{* * * a}$ & $437 \pm 26.87^{* * * a \neq \neq \neq \neq \neq \mathbf{b}}$ \\
\hline $\mathrm{DC}+\mathrm{OO}$ & $359 \pm 19.79$ & $263 \pm 21.21^{* * * a}$ & $201 \pm 15.55^{* * * a}$ & $163.5 \pm 21.92^{* * * a \neq a \neq \neq \neq \mathbf{b} \neq \neq \neq \mathbf{c}}$ \\
\hline $\mathrm{DC}+\mathrm{TH}$ & $320 \pm 20.19$ & $300 \pm 60.12$ & $261 \pm 30.15$ & $240.14 \pm 30.89^{* * \mathbf{a} \neq \neq \neq \mathbf{b} \neq \neq \neq \mathbf{c}}$ \\
\hline $\mathrm{DC}+\mathrm{OO}+\mathrm{TH}$ & $318 \pm 30.21$ & $260.18 \pm 42.40^{* a}$ & $200.80 \pm 12.56^{* * * a}$ & $158.54 \pm 20.42^{* * * a} \mathbf{a} \neq \neq \neq \mathbf{b} \neq \neq \neq \mathbf{c}$ \\
\hline
\end{tabular}

Data are expressed as mean \pm SD; a: comparison between day 0 and the other days, b: comparison between the control group (DW) and all groups on day 30 , and c: comparison between the diabetic group (DC) and all groups on day $30\left({ }^{*} p<0.05,{ }^{* *} p<0.01\right.$, and $\left.{ }^{* * *} p<0.001\right)$.

The diastatic activity is an index of freshness and heat treatment of honey. For our sample, we found a value of $15.43 \pm 2.03$ (shading units/g) which complies with the standard set at a value greater than 8 by the EU Council [59]. This confirms that our honey has not been overheated, is fresh, and has been stored very well.

The TSS percentage in thyme honey was $81.0 \pm 0.21$. According to the United States Standards for Grades of Extracted Honey (USDA) [60], if the value of TSS was more than $80 \%$, we can classify the honey sample as high grade and can be highly stable during storage.

3.4.2. Physicochemical Parameters of Olive Oil. Physicochemical analyses of olive oil are presented in Table 4. Free acidity is a quality factor of olive oil, the result of free acidity in our analyzed sample was $0.56 \pm 0.01 \%$. According to the criteria cited by the Commercial Standard of the International Olive Oil Council, the olive oil analyzed is classed as the extra virgin type (acidity less than 0.8) [61].

The peroxide index in olive oil was $4.6 \pm 0.04 \mathrm{mEq} \mathrm{O}_{2} / \mathrm{kg}$; this value is within the limits established by the commercial standard of the International Olive Oil Council $(\leq 20 \mathrm{mEq}$ $\mathrm{O}_{2} / \mathrm{kg}$ ) [61].

The values of specific ultraviolet extinctions K232 and K270 were $0.08 \pm 0.00$ and $0.21 \pm 0.00$, respectively. These values do not exceed the limits established by the commercial standard of the International Olive Oil Council $(\mathrm{K} 232=2.60$ and $\mathrm{K} 270=0.25)$ [61].

The chlorophyll and carotenoids contents were $14.55 \pm 1.02 \mathrm{mg} / \mathrm{kg}$ and $6.2 \pm 0.7 \mathrm{mg} / \mathrm{kg}$, respectively.

\subsection{Effect of Thyme Honey, Olive Oil, and Their Combination} on Blood Glucose Level. In the present study, the protective effect of thyme honey and olive oil was investigated against type 1 diabetes; it is a genetically determined disease that causes low or no insulin production in the body, and subsequently, an increase in the blood glucose level [25]. Table 5 shows that after a single intravenous injection of alloxan monohydrate $(65 \mathrm{mg} / \mathrm{kg} \mathrm{BW})$, the blood glucose level was increased significantly in rats injected compared to the groups of rats not injected by alloxan. The treatment of diabetic rats with thyme honey significantly decreased the blood glucose from $(320 \pm 20.19 \mathrm{mg} / \mathrm{dl})$ on day 0 to
$(240.14 \pm 30.89 \mathrm{mg} / \mathrm{dl})$ on day 30 ; similarly, the treatment with olive oil decreased the glycemia from $359 \pm 19.79 \mathrm{mg} /$ $\mathrm{dl}$ on day 0 to $163.5 \pm 21.92 \mathrm{mg} / \mathrm{dl}$ in day 30 . Interestingly, the combination of thyme honey and olive oil significantly decreased the blood glucose level from $(318 \pm 30.21 \mathrm{mg} / \mathrm{dl})$ on day 0 to $(158.54 \pm 20.42 \mathrm{mg} / \mathrm{dl})$ on day 30 . The hypoglycemic effect of thyme honey may be related to its phenolics composition (gallic acid $(2.86 \pm 0.046 \mathrm{mg} / 100 \mathrm{~g}$ ); ferulic acid $(0.68 \pm 0.021 \mathrm{mg} / 100 \mathrm{~g})$, caffeic acid $(0.033 \pm 0.00 \mathrm{mg} / 100 \mathrm{~g})$, epicatechin gallate $(6.91 \pm 0.05 \mathrm{mg} /$ $100 \mathrm{~g})$, and pyrogallol $(3.5 \pm 0.009 \mathrm{mg} / 100 \mathrm{~g}))$ [33]. Huang et al. have shown that gallic acid can ameliorate hyperglycemia and improves hepatic carbohydrate metabolism in diabetes induced by high-fructose diet in rats [62]. Similarly, it has been shown that caffeic acid has an antidiabetic effect via the inhibition of $\alpha$-amylase and $\alpha$-glucosidase [63] as well as epicatechin gallate supplementation can alleviate diabetes and lowered the glycemia level [64]. In addition, it is suggested that the fructose content of honey may contribute to the hypoglycemic effect of honey [65].

Many studies related the hypoglycemic effect of olive oil with its phenolic constituents. It has been proved that oleuropein, hydroxytyrosol, tyrosol, syringic acid, cinnamic acid, luteolin, and apigenin found in our olive oil sample (Table 2) have an important hypoglycemic effect [66-70].

3.6. Effect of Thyme Honey, Olive Oil, and Their Combination on Body Weight of Diabetic and Nondiabetic Rats. In the absence of insulin, the glucose is accumulated in the blood because it is neither stored in the liver nor used by the body's cells. At this condition, the body cells try to find another alternative to glucose using proteins and fats to produce the energy necessary for its functioning, this explains the weight loss in type 1 diabetics [70]. The change in body weight in diabetic rats and nondiabetic rats is shown in Table 6; the results revealed that the body weight of diabetic rats is significantly decreased, while in rats treated with thyme honey, olive oil, or by their combination, the body weight reduction statistically was not significant.

3.7. Effect of Thyme Honey, Olive Oil, and Their Combination on Hepatic Enzymes Level of Diabetic and Nondiabetic Rats. 
TABLE 6: Effect of daily oral administration of thyme honey, olive oil, and their combination on body weight.

\begin{tabular}{lccc}
\hline Experimental groups & & Body weight $(\mathrm{g})$ & \\
& Day 0 (baseline) & Day 30 & Body weight change \\
\hline DW & $180 \pm 6$ & $220 \pm 10$ & $+40 \pm 4$ \\
OO & $195 \pm 3$ & $221 \pm 14^{* *}$ & $+26 \pm 11$ \\
TH & $190 \pm 4$ & $212 \pm 9$ & $+22 \pm 5$ \\
DC & $193 \pm 5$ & $125 \pm 15^{*}$ & $-68 \pm 10$ \\
DC + OO & $178 \pm 7$ & $165 \pm 9$ & $-13 \pm 2$ \\
DC + TH & $199 \pm 7$ & $170 \pm 8$ & $-29 \pm 1$ \\
DC + OO + TH & $201 \pm 4$ & $178 \pm 7$ & $-23 \pm 3$ \\
\hline
\end{tabular}

Data are expressed as mean $\pm \mathrm{SD}$; the comparison between day 0 and day 30 was made using a $t$-test.

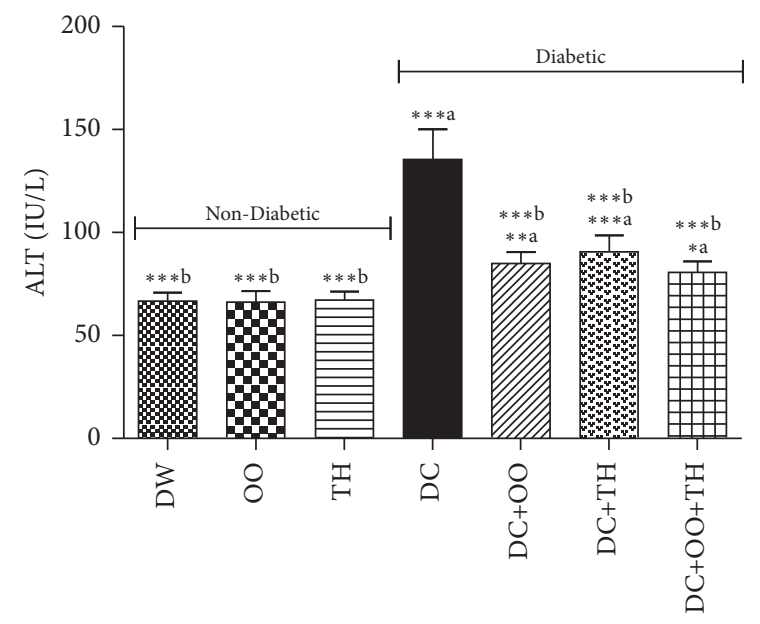

(a)

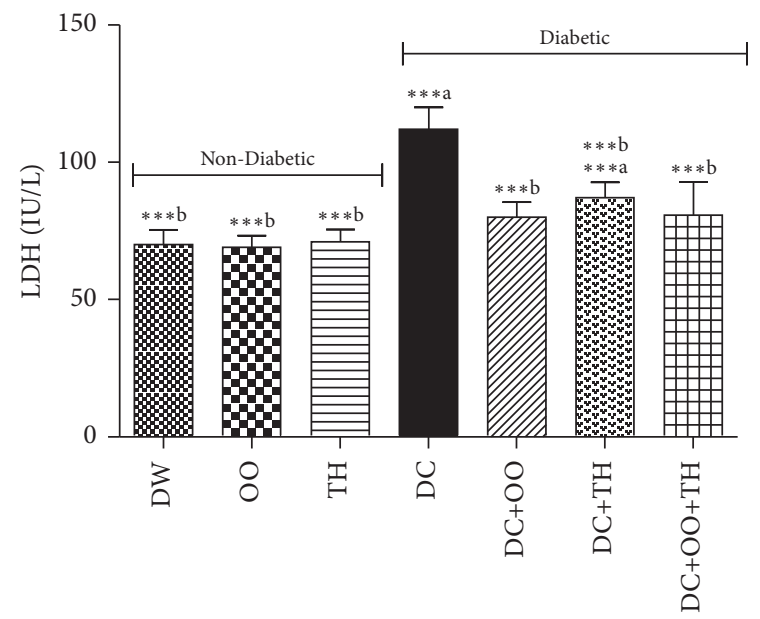

(c)

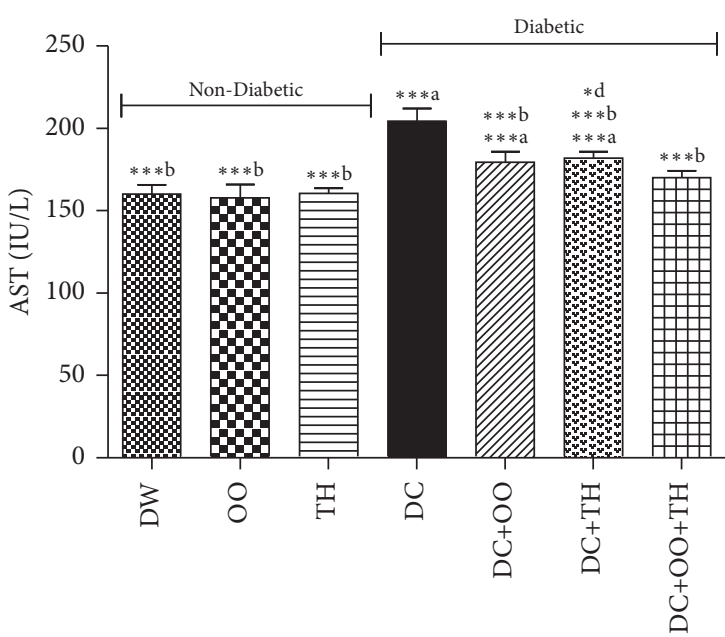

(b)

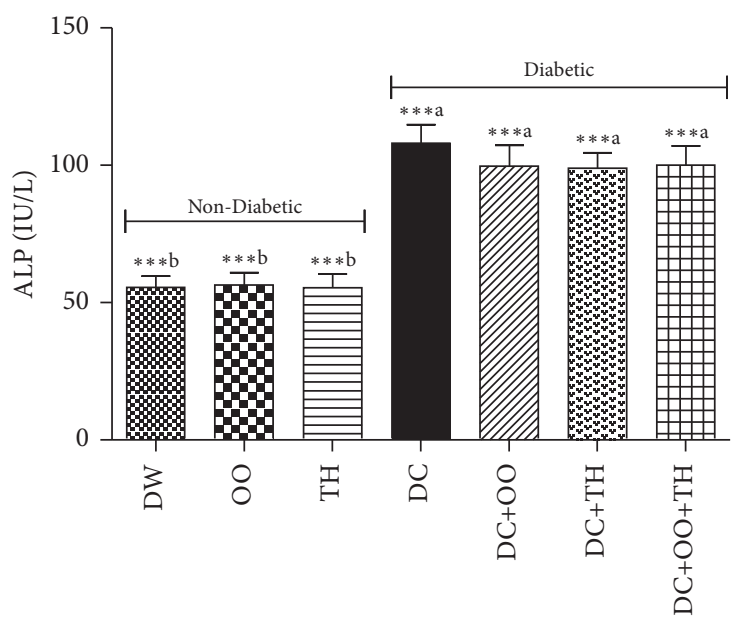

(d)

Figure 1: Effect of daily administration of thyme honey, olive oil, and their combination on hepatic enzymes level of diabetic and nondiabetic rats. Data are presented as mean \pm SD; (a) comparison between the distilled water group (DW) and all groups; (b) comparison between the diabetic nontreated group (DC) and all groups; (c) comparison between the diabetic group treated by olive oil (DC + OO) and the diabetic group treated by thyme honey $(\mathrm{DC}+\mathrm{TH})$; $(\mathrm{d})$ comparison between the diabetic group treated by the combination between olive oil and thyme honey $(\mathrm{DC}+\mathrm{OO}+\mathrm{TH})$ and the groups treated by olive oil only $(\mathrm{DC}+\mathrm{OO})$ or thyme honey only $(\mathrm{DC}+\mathrm{TH})$.

The effect of thyme honey, olive oil, and their combination on the hepatic enzyme level of diabetic and nondiabetic rats is presented in Figure 1; the results showed that all hepatic enzymes (ALP, AST, LDH, ALP) were significantly increased in diabetic non-treated rats, while in the groups of rats treated with olive oil, thyme honey, or their combination, the rats were protected against the increase of AST, ALP, and LDH, and they are not protected against the 


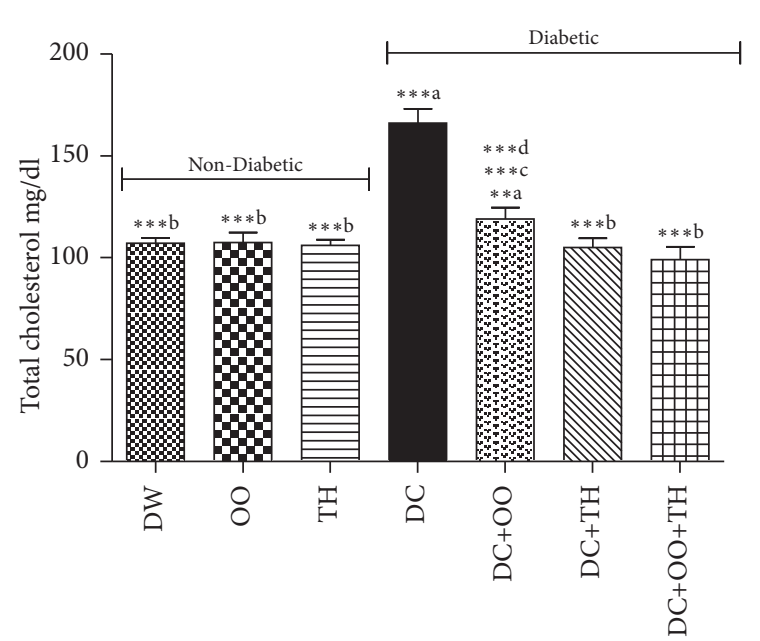

(a)

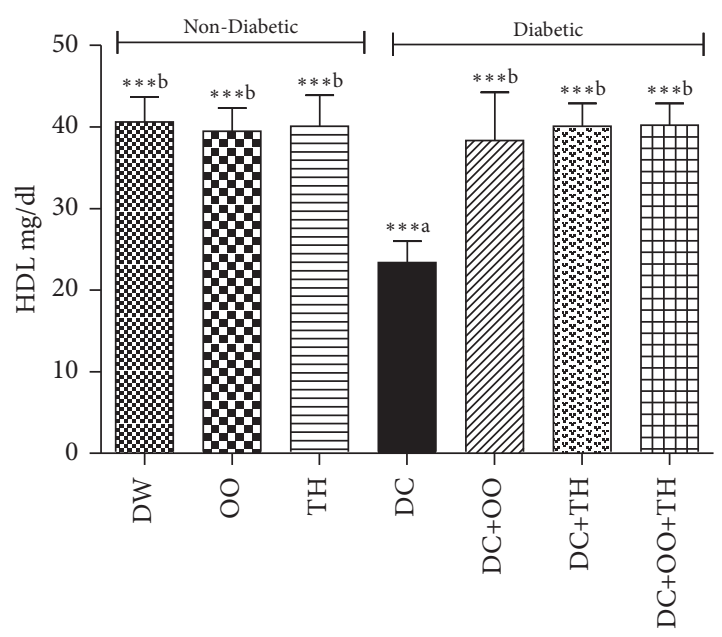

(c)

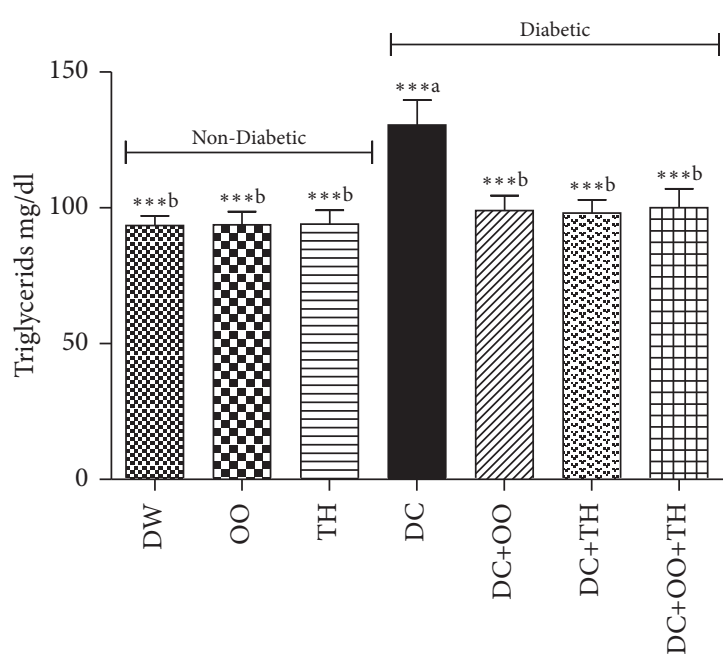

(b)

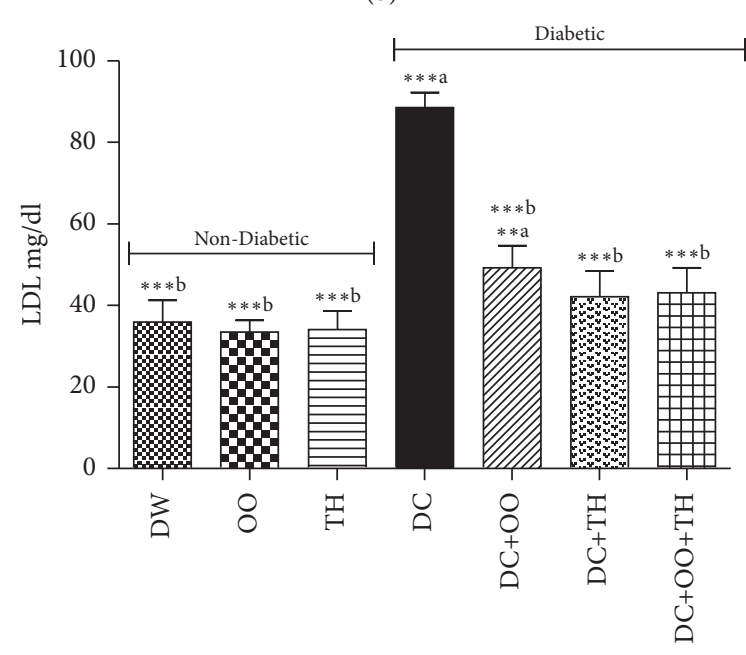

(d)

FIGURE 2: Effect of daily administration of thyme honey, olive oil, and their combination on the lipidic profile of diabetic and nondiabetic rats. Data are presented as mean $\pm \mathrm{SD}$; (a) comparison between the distilled water group (DW) and all groups; (b) comparison between the diabetic nontreated group (DC) and all groups; (c) comparison between the diabetic group treated by olive oil (DC $+\mathrm{OO})$ and the diabetic group treated by thyme honey $(\mathrm{DC}+\mathrm{TH})$; (d) comparison between the diabetic group treated by the combination between olive oil and thyme honey $(\mathrm{DC}+\mathrm{OO}+\mathrm{TH})$ and the groups treated by olive oil only $(\mathrm{DC}+\mathrm{OO})$ or thyme honey only $(\mathrm{DC}+\mathrm{TH})$.

elevation of ALP enzymes. The increase of the hepatic enzymes is due to the liver damage induced by diabetes toxicity and the leakage of these enzymes into the bloodstream [71]. The protective effect of olive oil and thyme honey is probably due to their phenolics content [72].

\subsection{Effect of Thyme Honey, Olive Oil, and Their Combination} on Lipid Profile of Diabetic and Nondiabetic Rats. Dyslipidemia is among the most well-known complications of diabetes; it is highly related to the risk of cardiovascular disease [73]. Figure 2 presents the effect of the daily administration of thyme honey, olive oil, and their combination on the lipid profile in diabetic and nondiabetic rats. The results showed that the dose of alloxan injection caused type 1 diabetes and led to dyslipidemia (the increase in total cholesterol, triglycerides, LDL, and decrease in HDL levels).
The same results were obtained by others authors using alloxan or streptozotocin as diabetogenic agents $[74,75]$. The groups of rats treated with thyme honey, olive oil, or their combination have protected the diabetic rats against this metabolic disorder in a significant manner $(p<0.001)$.

\subsection{Effect of Thyme Honey, Olive Oil, and Their Combination} on Kidney Parameters of Diabetic and Nondiabetic Rats. Kidney dysfunction is known as a complication of diabetes [76]. Figures 3 and 4 summarize the results of the effect of thyme honey, olive oil, and their combination on kidney parameters analyzed in urine and serum of diabetic and nondiabetic rats. The results revealed an increase in the serum levels of urea, uric acid, and creatinine in diabetic rats nontreated compared to the values obtained in control rats, while no change was recorded in total protein, potassium, 


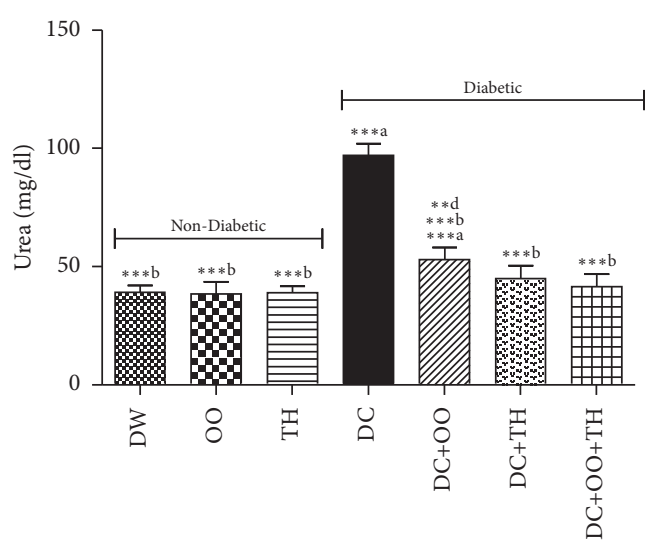

(a)

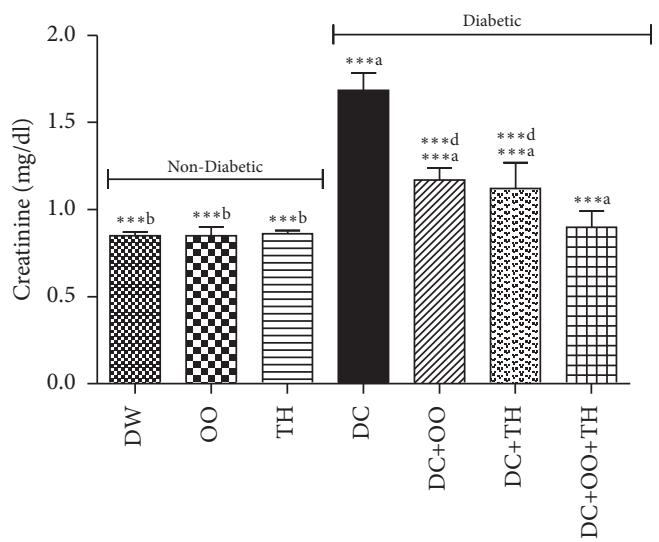

(c)

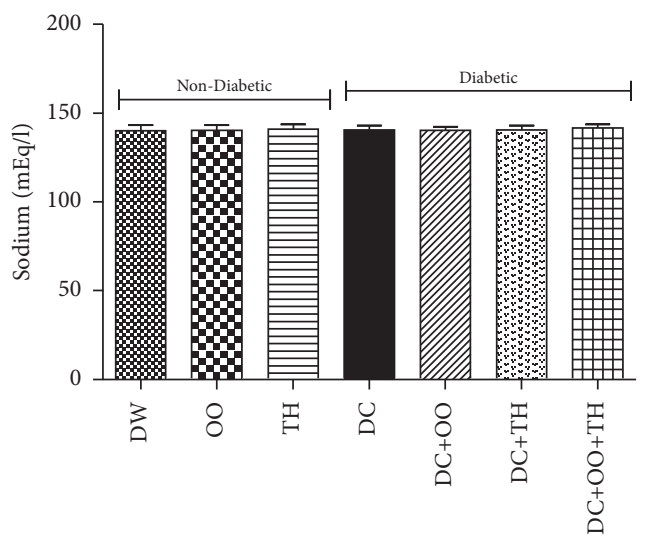

(e)

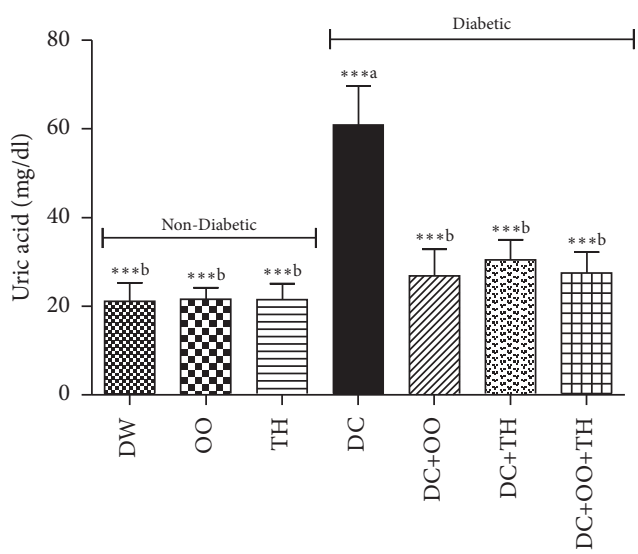

(b)

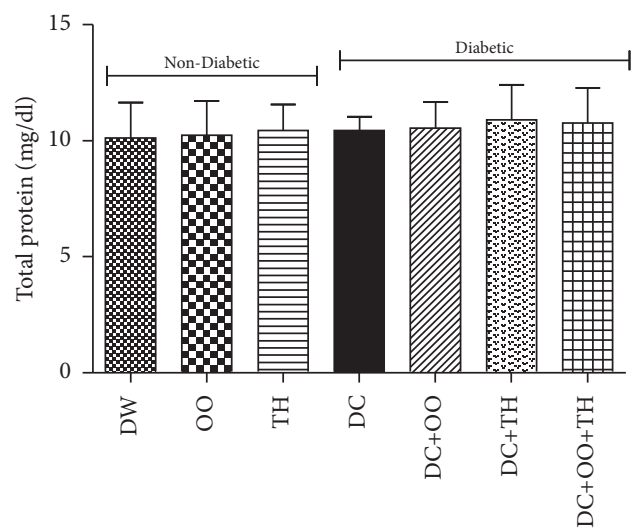

(d)

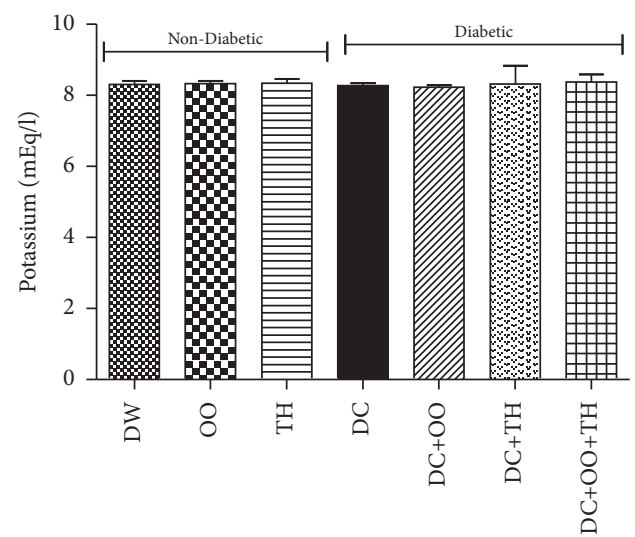

(f)

FIgURE 3: Continued. 


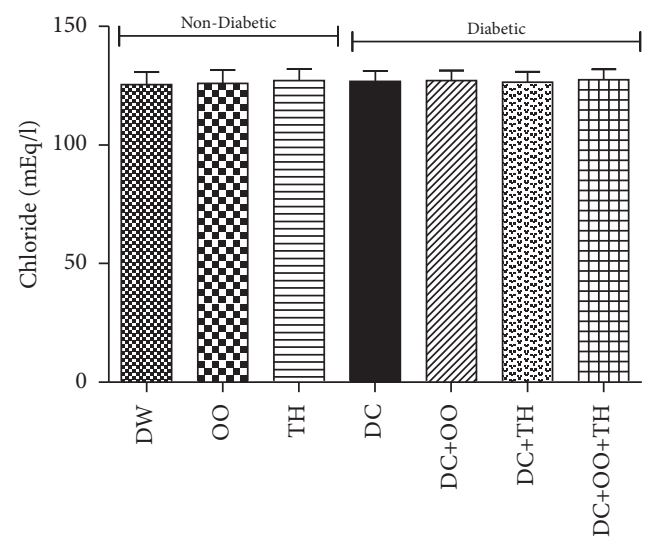

(g)

FIGURE 3: Effect of daily administration of thyme honey, olive oil, and their combination on serum kidney parameters of diabetic and nondiabetic rats. Data are presented as mean \pm SD; (a) comparison between the distilled water group (DW) and all groups; (b) comparison between the diabetic nontreated group (DC) and all groups; (c) comparison between the diabetic group treated by olive oil (DC + OO) and the diabetic group treated by thyme honey $(\mathrm{DC}+\mathrm{TH}) ;(\mathrm{d})$ comparison between the diabetic group treated by the combination between olive oil and thyme honey $(\mathrm{DC}+\mathrm{OO}+\mathrm{TH})$ and the groups treated by olive oil only $(\mathrm{DC}+\mathrm{OO})$ or thyme honey only $(\mathrm{DC}+\mathrm{TH})$.

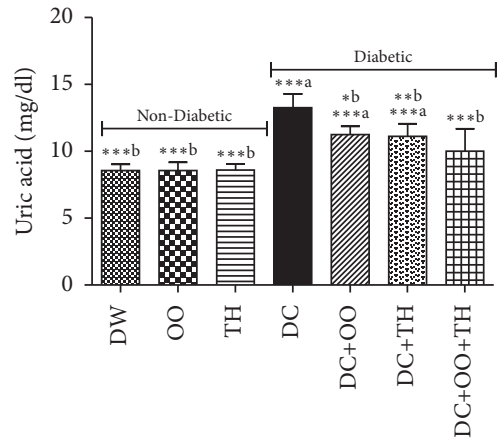

(a)

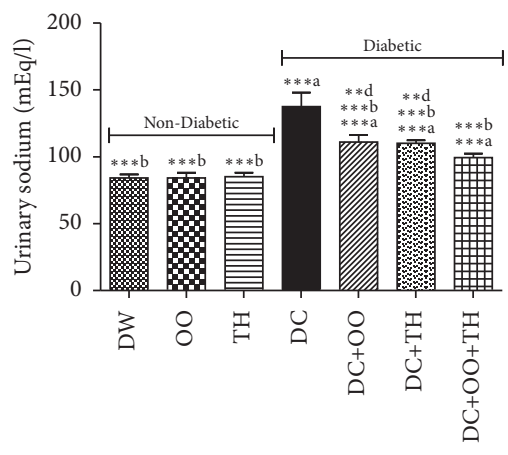

(d)

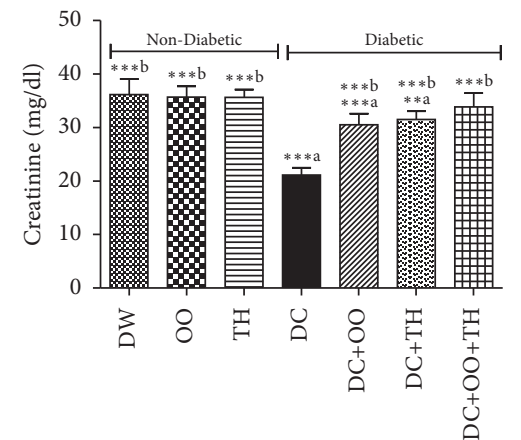

(b)

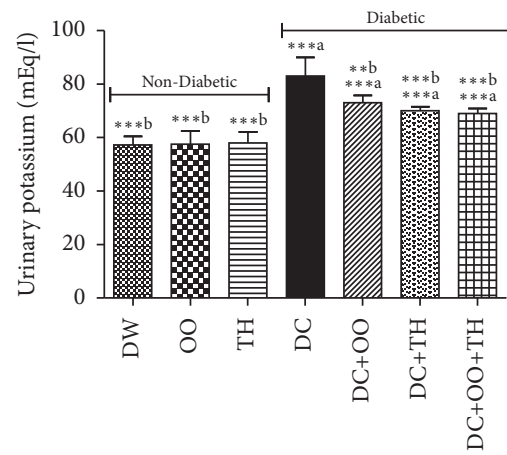

(e)

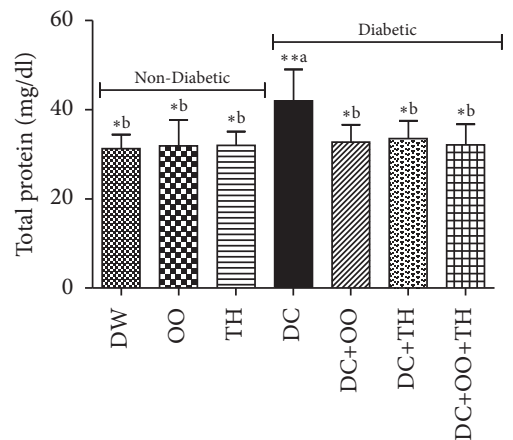

(c)

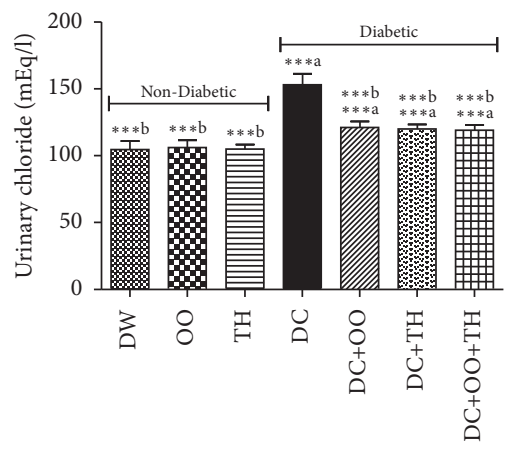

(f)

Figure 4: Effect of daily administration of thyme honey, olive oil, and their combination on urinary kidney parameters of diabetic and nondiabetic rats. Data are presented as mean $\pm \mathrm{SD}$; (a) comparison between the distilled water group (DW) and all groups; (b) comparison between the diabetic nontreated group (DC) and all groups; (c) comparison between the diabetic group treated by olive oil (DC + OO) and the diabetic group treated by thyme honey $(\mathrm{DC}+\mathrm{TH}) ;(\mathrm{d})$ comparison between the diabetic group treated by the combination between olive oil and thyme honey $(\mathrm{DC}+\mathrm{OO}+\mathrm{TH})$ and the groups treated by olive oil only $(\mathrm{DC}+\mathrm{OO})$ or thyme honey only $(\mathrm{DC}+\mathrm{TH})$. 


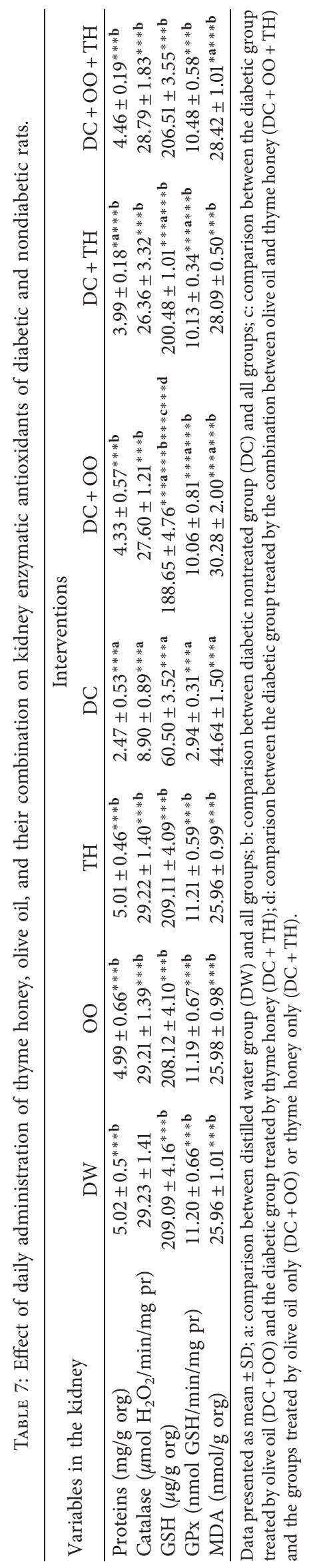




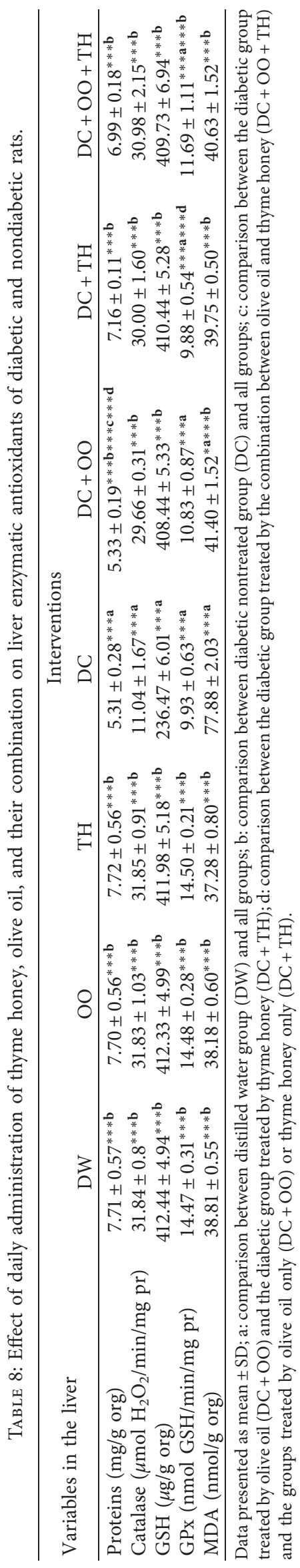




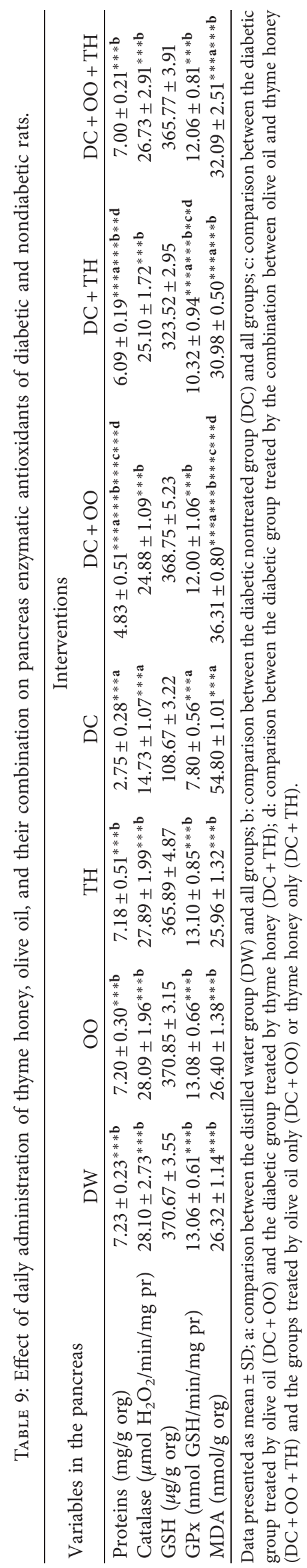




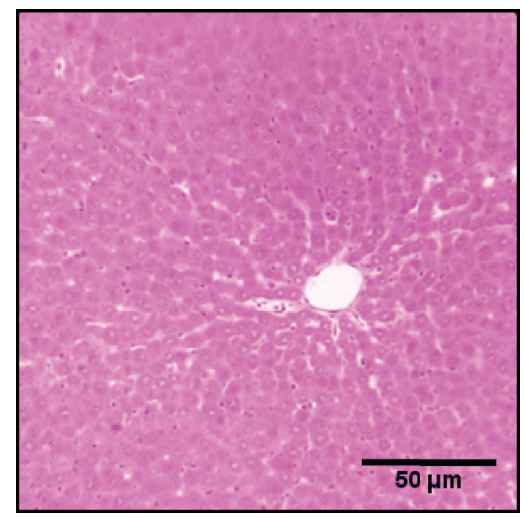

(a)

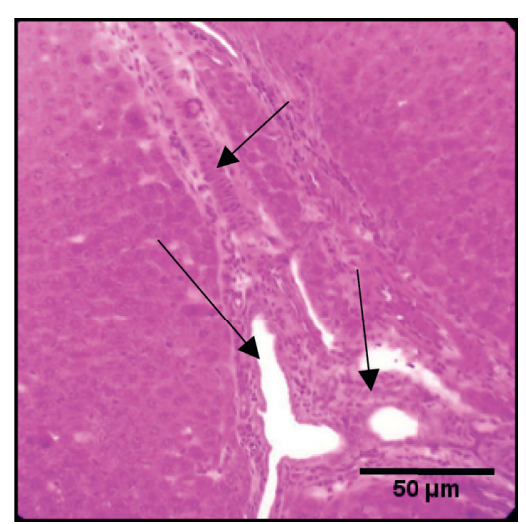

(b)

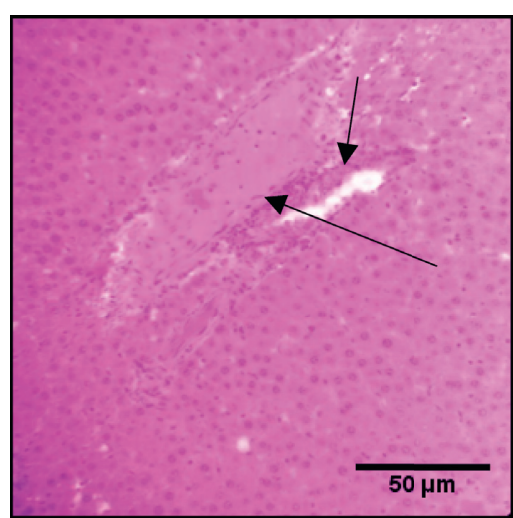

(c)

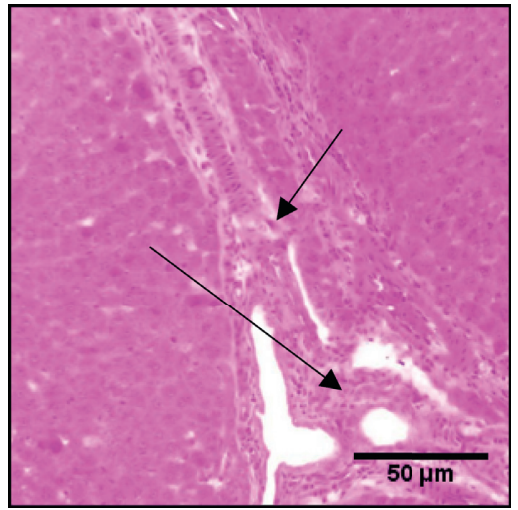

(d)

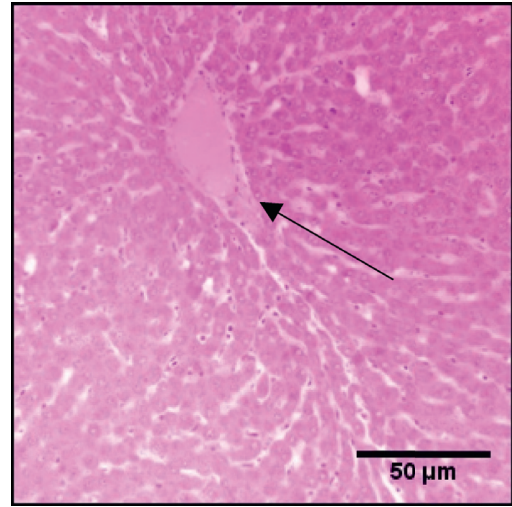

(e)

FIGURE 5: Effect of thyme honey, olive oil, and thyme combination on the liver tissue of diabetic and nondiabetic rats. (a) DW group, (b) diabetic untreated group (DC), (c) diabetic group treated with olive oil, (d) diabetic group treated with thyme honey, and (e) diabetic group treated with thyme honey and olive oil.

sodium, and chloride levels. The treatment of diabetic rats with olive oil, thyme honey, or their combination has a protective effect against the elevation of urea, uric acid, and creatinine in diabetic treated rats. For the urine analysis, the injection of alloxan leads to an increase in urine uric acid, creatinine, total protein, and the urinary excretion of sodium, potassium, and chloride. It was revealed that the main cause of diabetic kidney toxicity is oxidative stress. Thereby, supplementation with phenolic acids may be effective against this toxicity [77].

\subsection{Effect of Thyme Honey, Olive Oil, and Their Combination} on the Kidney, Pancreas, and Liver Enzymatic Antioxidants and Lipid Peroxidation of Diabetic and Nondiabetic Rats. Oxidative stress is known as an imbalance between free radicals and antioxidants in the body [78]. Several studies proved that diabetes is accompanied by oxidative stress and increased free radical formation $[79,80]$. Tables 7-9 summarize the effect of thyme honey, olive oil, and their combination on the kidney, pancreas, and liver enzymatic antioxidants of diabetic and nondiabetic rats. The results presented in these Tables showed that in the three organs (kidney, liver, and pancreas), the levels of proteins, catalase, GSH, and GPx were significantly decreased $(p<0.001)$, while the MDA was increased in the same manner in diabetic nontreated rats. In the treated rats whether, by thyme honey, olive oil, or by their combination, we observed a significant increase in enzymatic antioxidant levels and a decrease in MDA levels. Increasing enzymatic and nonenzymatic antioxidants in the body is the most important strategy to prevent lipid peroxidation and to fight oxidative stress which is the main cause of the onset of diabetic complications [81].

\subsection{Effect of Thyme Honey, Olive Oil, and Their Combination} on the Liver, Kidney, and Pancreas Tissues of Diabetic and Nondiabetic Rats. Liver histological analysis is illustrated in Figure 5. The liver of the nondiabetic group that received distilled water only revealed normal microscopic architecture formed by Pacini hexagonal lobules which centered on the central vein (Figure 5(a)). In the diabetic untreated group (Figure 5(b)), the liver structure revealed congestion of the central vein with disorganization of hepatic architecture, which could induce severe destruction and necrosis. The administration of honey and olive oil at the dose of $2 \mathrm{mg} / \mathrm{kg}$ and $10 \mathrm{mg} / \mathrm{kg}$, respectively, or combined exhibited a morphology near to that of the control structure for olive oil (Figure 5(c)). The combination of olive oil and honey ameliorate congestion of the hepatic artery, mild dilatation of portal vein, and moderate disorganization of hepatic 


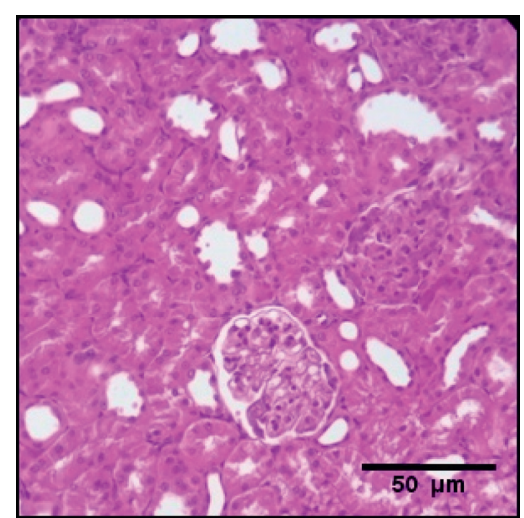

(a)

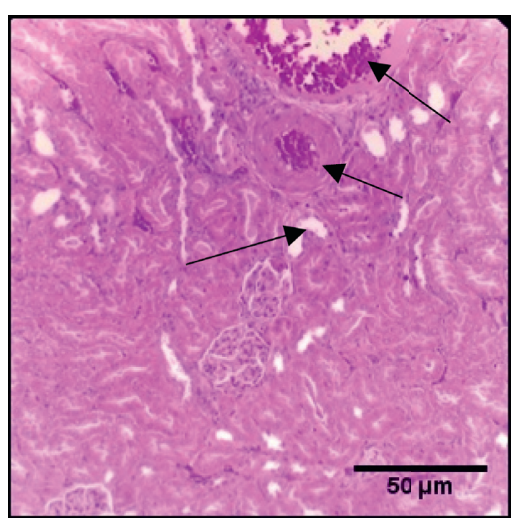

(b)

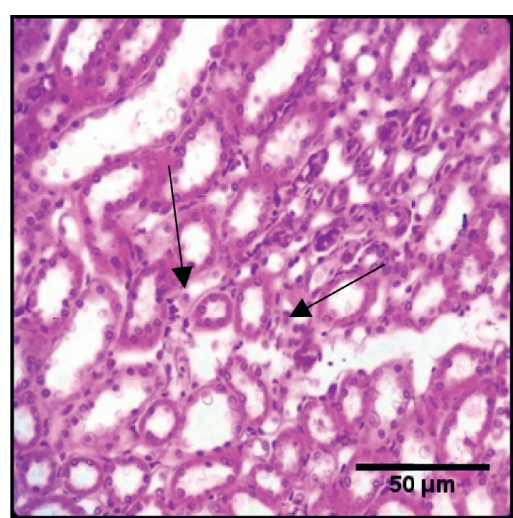

(c)

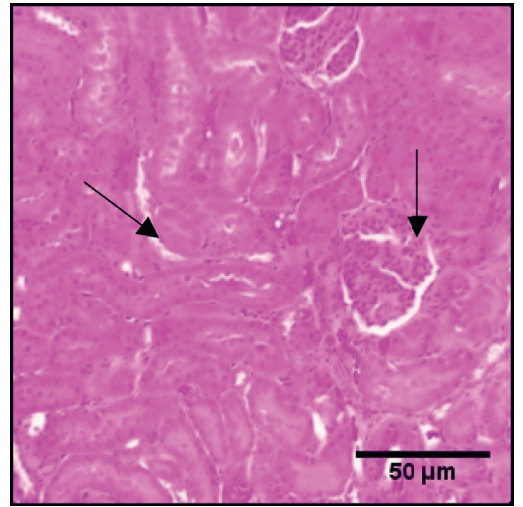

(d)

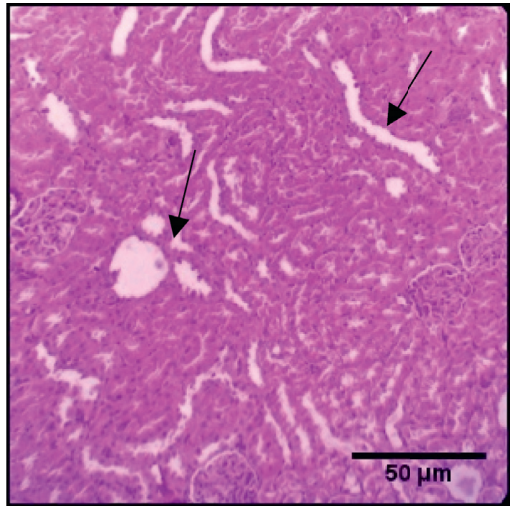

(e)

FIGURE 6: Effect of thyme honey, olive oil, and thyme combination on kidney tissue of diabetic and nondiabetic rats. (a) DW group, (b) diabetic untreated group (DC), (c) diabetic group treated with olive oil, (d) diabetic group treated with thyme honey, and (e) diabetic group treated with thyme honey and olive oil.

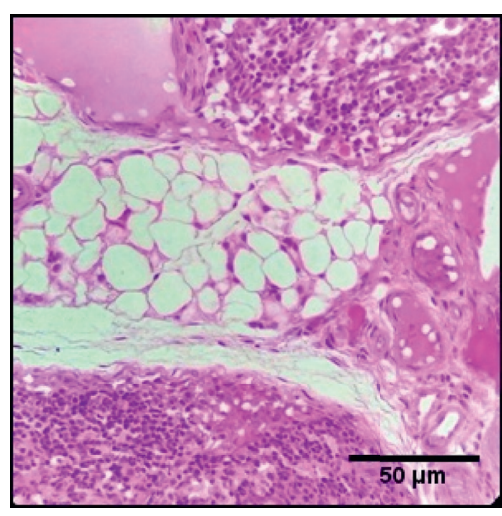

(a)

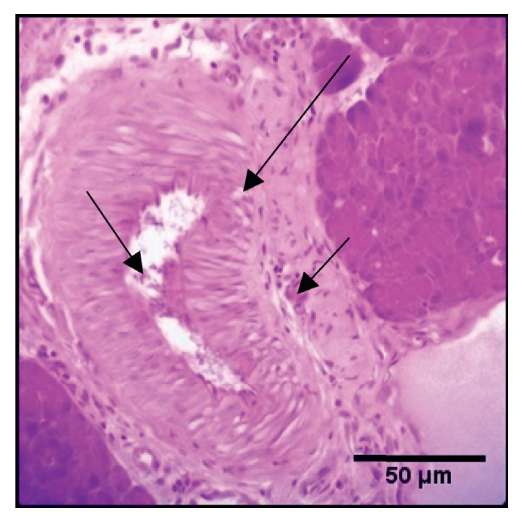

(b)

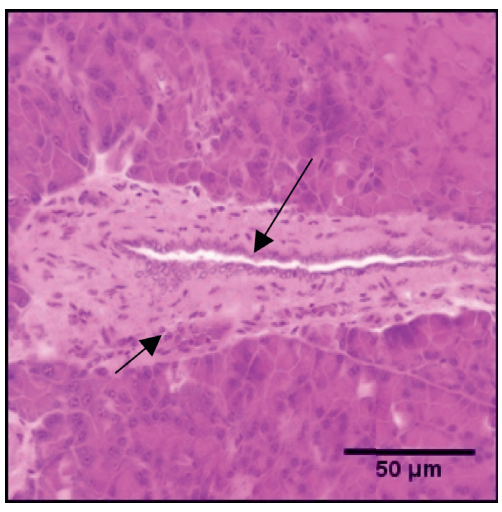

(c)

Figure 7: Continued. 


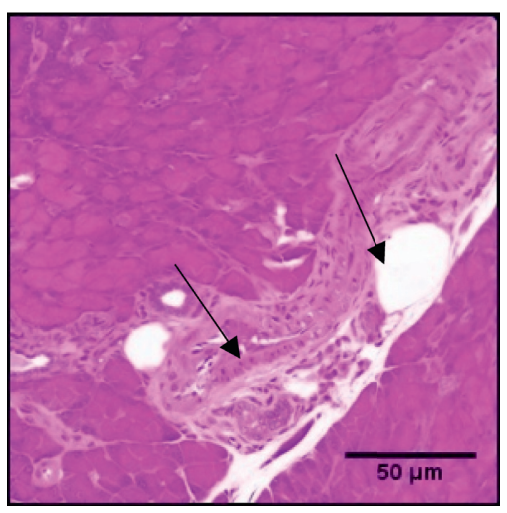

(d)

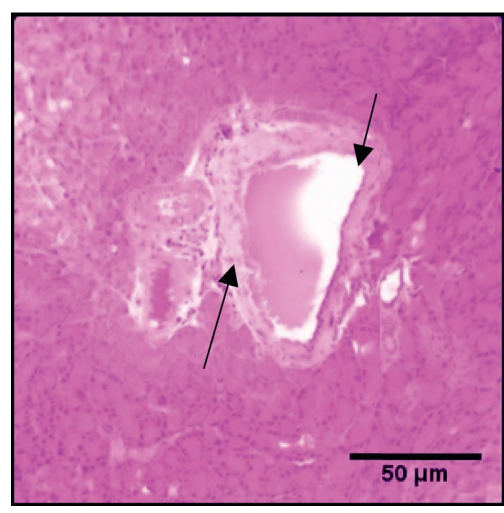

(e)

Figure 7: The effect of thyme honey, olive oil, and thyme combination on the pancreas tissue of diabetic and nondiabetic rats. (a) DW group, (b) diabetic untreated group (DC), (c) diabetic group treated with olive oil, (d) diabetic group treated with thyme honey, and (e) diabetic group treated with thyme honey and olive oil.

architecture (Figure 5(d)), while thyme honey treatment revealed a modest ability to counteract the alloxan's hepatic injuries (Figure 5(c)).

The histological analysis of the kidney was presented in Figure 6. The kidneys of diabetic untreated rats' revealed changes in the architecture (Figure 6(b)) as compared to the control group (Figure 6(a)). Furthermore, there is a decrease in Bowman's capsule space with disorganization of the kidney structure and renal vein dilatation. The renal tissue in groups treated with thyme honey or thyme honey/olive oil was well protected against injuries induced by alloxan (Figures 6(d) and 6(e)). While in the group treated with olive oil alone, the kidney histological examination showed a deposit of immune cells and vacuolar modification seen in the tubular cells (Figure 6(c)).

The histological analysis of pancreatic tissue is presented in Figure 7. The tissue of the untreated diabetic rats revealed necrotic changes induced by alloxan. It induced eosinophilia, increased cellular infiltration, hemorrhage, and disorganization of pancreatic structure (Figure $7(\mathrm{~b})$ ). However, the use of honey and olive oil alone or combined (Figures $7(\mathrm{c})-7(\mathrm{e})$ ) protect relatively the pancreatic architecture by recovering a structure close to that showed in the normal group (Figure 7(a)).

The histopathological changes of the liver, kidney, and pancreas showed in the diabetic group were previously observed in other studies $[82,83]$ because these organs are the main targets of the complications induced by diabetes. Olive oil and thyme honey exhibit a protective effect against these changes induced by a single injection of alloxan. The same results were observed in other studies like those of Balamash et al. showing that virgin olive oil from Saudi Arabia has a protective effect against the histopathological changes of the liver, pancreas, and kidneys induced by streptozotocin in Sprague-Dawley rats [84]. Similarly, Afroz et al. have shown that honey has a protective effect on histological changes of the liver and kidneys induced by acetaminophen [85].

\section{Conclusion}

Overall, we can conclude from the results obtained in this study that thyme honey or olive oil, and especially, their combination improved significantly the blood glucose levels and protected against metabolic changes and the complications induced by type 1 diabetes. More in-depth studies are needed to know the molecules responsible for the pharmacological effect observed in this study, as well as to understand the exact mechanism of action.

\section{Data Availability}

The data used to support the findings of this study are available from the corresponding author upon request.

\section{Conflicts of Interest}

The authors declare that there are no conflicts of interest regarding the publication of this paper.

\section{Acknowledgments}

The authors would like to thank Laboratory (SNAMOPEQ), Faculty of Sciences, Dhar El Mehraz, for providing the facilities to carry out the research work. The study was funded by the University Sidi Mohamed Ben Abdallah, P.O. Box 1796, Fez. Atlas, Fez. Morocco (USMBA/PPSE/L08 FSDM 2018).

\section{References}

[1] American Diabetes Association, "Diagnosis and classification of diabetes mellitus," Diabetes Care, vol. 36, pp. S67-S74, 2013.

[2] S. Wild, G. Roglic, A. Green, R. Sicree, and H. King, "Global prevalence of diabetes: estimates for the year 2000 and projections for 2030," Diabetes Care, vol. 27, no. 5, pp. 1047-1053, 2004. 
[3] D. Meetoo, "Diabetes: complications and the economic burden," British Journal of Healthcare Management, vol. 20, no. 2, pp. 60-67, 2014.

[4] P. Chhabra, K. L. Brayman, and K. L. Brayman, "Stem cell therapy to cure type 1 diabetes: from hype to hope," Stem Cells Translational Medicine, vol. 2, no. 5, pp. 328-336, 2013.

[5] F. S. Malik, C. E. Taplin, and C. E. Taplin, "Insulin therapy in children and adolescents with type 1 diabetes," Pediatric Drugs, vol. 16, no. 2, pp. 141-150, 2014.

[6] A. Chaudhury, C. Duvoor, V. S. Reddy Dendi et al., "Clinical review of antidiabetic drugs: implications for type 2 diabetes mellitus management," Frontiers in Endocrinology, vol. 8, p. 6 , 2017.

[7] A. Zarinsefat, P. G. Stock, and P. G. Stock, "Islet vs. pancreas transplantation in nonuremic patients with type 1 diabetes," in Transplantation, Bioengineering, and Regeneration of the Endocrine Pancreas, pp. 417-423, Elsevier, Amsterdam, Netherlands, 2020.

[8] D. Patel, S. Prasad, R. Kumar, and S. Hemalatha, "An overview on antidiabetic medicinal plants having insulin mimetic property," Asian Pacific Journal of Tropical Biomedicine, vol. 2, no. 4, pp. 320-330, 2012.

[9] Z. Zaheen, A. M. Yatoo, S. Ali et al., "Honey: types, composition and antimicrobial mechanisms," in Therapeutic Applications of Honey and its PhytochemicalsSpringer, Berlin, Germany, 2020.

[10] J. Louveaux, A. Maurizio, and G. Vorwohl, "Methods of melissopalynology," Bee World, vol. 59, no. 4, pp. 139-157, 1978.

[11] A. A. Machado De-Melo, L. B. D. Almeida-Muradian, M. T. Sancho, and A. Pascual-Maté, "Composition and properties of Apis mellifera honey: a review," Journal of Apicultural Research, vol. 57, no. 1, pp. 5-37, 2018.

[12] T. eraf-Oskouei and M. Najafi, "Traditional and modern uses of natural honey in human diseases: a review," Journal of Basic Medical Sciences, vol. 16, no. 6, p. 731, 2013.

[13] M. Johnston, M. McBride, M. McBride, D. Dahiya, R. OwusuApenten, and P. Singh Nigam, "Antibacterial activity of Manuka honey and its components: an overview," AIMS Microbiology, vol. 4, no. 4, pp. 655-664, 2018.

[14] F. C. Biluca, B. da Silva, T. Caon et al., "Investigation of phenolic compounds, antioxidant and anti-inflammatory activities in stingless bee honey (Meliponinae)," Food Research International, vol. 129, Article ID 108756, 2020.

[15] R. Bt Hj Idrus, N. Q. A. V. Sainik, A. Nordin, A. B. Saim, and N. Sulaiman, "Cardioprotective effects of honey and its constituent: an evidence-based review of laboratory studies and clinical trials," International Journal of Environmental Research and Public Health, vol. 17, no. 10, p. 3613, 2020.

[16] A. Z. Mohd Rafie, A. Syahir, W. A. N. Wan Ahmad, M. Z. Mustafa, and A. R. Mariatulqabtiah, "Supplementation of stingless bee honey from heterotrigona itama improves antiobesity parameters in high-fat diet induced obese rat model," Evidence-based Complementary and Alternative Medicine, vol. 2018, Article ID 6371582, 10 pages, 2018.

[17] M. Z. Mustafa, F. N. Zulkifli, I. Fernandez et al., "Stingless bee honey improves spatial memory in mice, probably associated with brain-derived neurotrophic factor (BDNF) and inositol 1,4,5-triphosphate receptor type 1 (Itpr1) genes," Evidencebased Complementary and Alternative Medicine, vol. 2019, Article ID 8258307, 11 pages, 2019.

[18] S. Şahin and M. Bilgin, "Olive tree (Olea europaea L.) leaf as a waste by-product of table olive and olive oil industry: a review," Journal of the Science of Food and Agriculture, vol. 98, no. 4, pp. 1271-1279, 2018.

[19] B. Gargouri, S. Ammar, A. Zribi, A. B. Mansour, and M. Bouaziz, "Effect of growing region on quality characteristics and phenolic compounds of chemlali extra-virgin olive oils," Acta Physiologiae Plantarum, vol. 35, no. 9, pp. 2801-2812, 2013.

[20] S. Dabbou, S. Sifi, I. Rjiba et al., "Effect of pedoclimatic conditions on the chemical composition of the Sigoise Olive cultivar," Chemistry and Biodiversity, vol. 7, no. 4, pp. 898-908, 2010.

[21] L. Guo, S. Gong, Y. Wang, Q. Sun, K. Duo, and P. Fei, "Antibacterial activity of olive oil polyphenol extract against Salmonella typhimurium and Staphylococcus aureus: possible mechanisms," Foodborne Pathogens and Disease, vol. 17, no. 6, pp. 396-403, 2020.

[22] A. Luque-Sierra, L. Alvarez-Amor, R. Kleemann, F. Martín, and L. M. Varela, "Extra-virgin olive oil with natural phenolic content exerts an anti-inflammatory effect in adipose tissue and attenuates the severity of atherosclerotic lesions in Ldlr-/ -. Leiden mice," Molecular Nutrition \& Food Research, vol. 62, no. 13, Article ID 1800295, 2018.

[23] W. A. A. Osman, D. A. Labib, M. O. Abdelhalim, and E. M. Elrokh, "Synergistic analgesic, anti-pyretic and antiinflammatory effects of extra virgin olive oil and ibuprofen in different experimental models of albino mice," International Journal of Rheumatic Diseases, vol. 20, no. 10, pp. 1326-1336, 2017.

[24] J. Torić, A. Karković Marković, C. Jakobušić Brala, and M. Barbarić, "Anticancer effects of olive oil polyphenols and their combinations with anticancer drugs," Acta Pharmaceutica, vol. 69, no. 4, pp. 461-482, 2019.

[25] O. Bobiş, D. S. Dezmirean, and A. R. Moise, "Honey and diabetes: the importance of natural simple sugars in diet for preventing and treating different type of diabetes," Oxidative Medicine and Cellular Longevity, vol. 2018, Article ID 4757893, 12 pages, 2018.

[26] M. A. Hashmi, A. Khan, M. Hanif, U. Farooq, and S. Perveen, "Traditional uses, phytochemistry, and Pharmacology of Olea europaea (olive)," Evidence-based Complementary and Alternative Medicine, vol. 2015, Article ID 541591, 29 pages, 2015.

[27] A. Alkhatib, C. Tsang, A. Tiss et al., "Functional foods and lifestyle approaches for diabetes prevention and management," Nutrients, vol. 9, no. 12, 12 pages, Article ID 1310, 2017.

[28] M. Bakour, N. Soulo, N. Hammas et al., "The antioxidant content and protective effect of argan oil and syzygium aromaticum essential oil in hydrogen peroxide-induced biochemical and histological changes," International Journal of Molecular Sciences, vol. 19, no. 2, p. 610, 2018.

[29] H. Laaroussi, T. Bouddine, M. Bakour, D. Ousaaid, and B. Lyoussi, "Physicochemical properties, mineral content, antioxidant activities, and microbiological quality of Bupleurum spinosum gouan honey from the middle atlas in Morocco," Journal of Food Quality, vol. 2020, Article ID 7609454, 12 pages, 2020.

[30] C. C. Nweze, M. G. Abdulganiyu, and O. G. Erhabor, "Comparative analysis of vitamin $\mathrm{c}$ in fresh fruits juice of Malus domestica, Citrus sinensi, Ananas comosus and citrullus lanatus by iodometric titration," International Journal of Science, Environment and Technology, vol. 4, no. 1, pp. 17-22, 2015. 
[31] M. d. G. Miguel, O. Doughmi, S. Aazza, D. Antunes, and B. Lyoussi, "Antioxidant, anti-inflammatory and acetylcholinesterase inhibitory activities of propolis from different regions of Morocco," Food Science and Biotechnology, vol. 23, no. 1, pp. 313-322, 2014.

[32] F. M. Pirisi, P. Cabras, C. F. Cao, M. Migliorini, and M. Muggelli, "Phenolic compounds in virgin olive oil. 2. Reappraisal of the extraction, HPLC separation, and quantification procedures," Journal of Agricultural and Food Chemistry, vol. 48, no. 4, pp. 1191-1196, 2000.

[33] H. Imtara, N. Al-Waili, A. Aboulghazi, A. Abdellaoui, T. AlWaili, and B. Lyoussi, "Chemical composition and antioxidant content of Thymus vulgaris honey and Origanum vulgare essential oil; their effect on carbon tetrachloride-induced toxicity," Veterinary World, vol. 14, no. 1, pp. 292-301, 2021.

[34] L. R. Silva, R. Videira, A. P. Monteiro, P. Valentão, and P. B. Andrade, "Honey from Luso region (Portugal): physicochemical characteristics and mineral contents," Microchemical Journal, vol. 93, no. 1, pp. 73-77, 2009.

[35] S. Bogdanov, Harmonised Methods of the International Honey Commission, Swiss Bee Research Centre, Liebefeld, Switzerland, 2002.

[36] O. A. Naab, M. A. Tamame, and M. A. Caccavari, "Palynological and physicochemical characteristics of three unifloral honey types from central Argentina," Spanish Journal of Agricultural Research, vol. 6, no. 4, pp. 566-576, 2008.

[37] K. Brudzynski, D. Miotto, and D. Miotto, "Honey melanoidins: analysis of the compositions of the high molecular weight melanoidins exhibiting radical-scavenging activity," Food Chemistry, vol. 127, no. 3, pp. 1023-1030, 2011.

[38] A. M. Giuffrè, "The evolution of free acidity and oxidation related parameters in olive oil during olive ripening from cultivars grown in the region of Calabria, South Italy," Emirates Journal of Food and Agriculture, pp. 539-548, 2018.

[39] European Community Commission, "Commission Regulation (EEC) No. 2568/91," Journal of European Community L022, vol. 5, no. 9, 1991.

[40] N. B. Youssef, W. Zarrouk, A. Carrasco-Pancorbo et al., "Effect of olive ripeness on chemical properties and phenolic composition of chétoui virgin olive oil," Journal of the Science of Food and Agriculture, vol. 90, no. 2, pp. 199-204, 2010.

[41] H. Aebi, "Catalase in vitro," Methods in Enzymology, vol. 105, pp. 121-126, 1984.

[42] W. A. G. L. Flohé, "Assays of glutathione peroxidase," Methods in Enzymology, vol. 105, Article ID 114121, 1984.

[43] G. L. Ellman, "Tissue sulfhydryl groups," Archives of Biochemistry and Biophysics, vol. 82, no. 1, pp. 70-77, 1959.

[44] M. Kassan, M. Montero, and M. Sevilla, "Chronic treatment with pravastatin prevents early cardiovascular changes in spontaneously hypertensive rats," British Journal of Pharmacology, vol. 158, no. 2, pp. 541-547, 2009.

[45] V. Lobo, A. Patil, A. Phatak, and N. Chandra, "Free radicals, antioxidants and functional foods: impact on human health," Pharmacognosy Reviews, vol. 4, no. 8, pp. 118-126, 2010.

[46] I. F. F. Benzie, S.-W. Choi, and S.-W. Choi, "Antioxidants in food: content, measurement, significance, action, cautions, caveats, and research needs," Advances in Food \& Nutrition Research, vol. 71, pp. 1-53, 2014.

[47] M. Benlyas, C. Alem, and Y. Filali-Zegzouti, "Evaluation of antioxidant, antibacterial and antifungal activities of eleven monofloral honey samples collected from Morocco," Journal of Chemical and Pharmaceutical Research, vol. 8, no. 3, pp. 299-306, 2016.
[48] A. Wilczynska, "Phenolic content and antioxidant activity of different types of polish honey-a short report," Polish Journal of Food and Nutrition Sciences, vol. 60, no. 4, 2010.

[49] C. Negro, A. Aprile, A. Luvisi et al., "Phenolic profile and antioxidant activity of Italian monovarietal extra virgin olive oils," Antioxidants, vol. 8, no. 6, p. 161, 2019.

[50] S. Charoenprasert, A. Mitchell, and A. Mitchell, "Factors influencing phenolic compounds in table olives (Olea europaea)," Journal of Agricultural and Food Chemistry, vol. 60, no. 29, pp. 7081-7095, 2012.

[51] B. Lanza, P. Ninfali, and P. Ninfali, "Antioxidants in extra virgin olive oil and table olives: connections between agriculture and processing for health choices," Antioxidants, vol. 9, no. 1, p. 41, 2020.

[52] M. Servili, A. Taticchi, S. Esposto, S. Urbani, R. Selvaggini, and G. Montedoro, "Influence of the decrease in oxygen during malaxation of olive paste on the composition of volatiles and phenolic compounds in virgin olive oil," Journal of Agricultural and Food Chemistry, vol. 56, no. 21, pp. 10048-10055, 2008.

[53] V. Pedan, M. Popp, S. Rohn, M. Nyfeler, and A. Bongartz, "Characterization of phenolic compounds and their contribution to sensory properties of olive oil," Molecules, vol. 24, no. 11, p. 2041, 2019.

[54] D. Angelino, L. Gennari, M. Blasa et al., "Chemical and cellular antioxidant activity of phytochemicals purified from olive mill waste waters," Journal of Agricultural and Food Chemistry, vol. 59, no. 5, pp. 2011-2018, 2011.

[55] N. Paquot and A. Scheen, "La place des micronutriments en medecine," Revue Medicale de Liege, vol. 61, no. 5-6, pp. 464-470, 2006.

[56] Commission Regulation, "Setting maximum levels for certain contaminants in foodstuffs," Official Journal of the European Union, vol. 1881, 2006.

[57] Codex Alimentarius Commission, "Revised codex standard for honey; codex stan,” Review, vol. 12, 1987.

[58] T. Ruiz-Argueso, A. Rodriguez-Navarro, and A. RodriguezNavarro, "Gluconic acid-producing bacteria from honey bees and ripening honey," Journal of General Microbiology, vol. 76, no. 1, pp. 211-216, 1973.

[59] EU Council, "Council directive 2001/11 O/EC of 20 december 2001 relating to honey," Official Journal of the European Communities, vol. 10, pp. 47-52, 2002.

[60] USDA, United States Standards for Grades of Extracted Honey, Agricultural Marketing Service, Washington, DC, USA, 1985.

[61] Conseil Oléicole International, Norme commerciale applicable aux huiles d'olive et aux l'huiles de grignions d'olive, Conseil Oléicole International, Madrid, Spain, 2011.

[62] D.-W. Huang, W.-C. Chang, J. S.-B. Wu, R.-W. Shih, and S.-C. Shen, "Gallic acid ameliorates hyperglycemia and improves hepatic carbohydrate metabolism in rats fed a highfructose diet," Nutrition Research, vol. 36, no. 2, pp. 150-160, 2016.

[63] G. Oboh, O. M. Agunloye, S. A. Adefegha, A. J. Akinyemi, and A. O. Ademiluyi, "Caffeic and chlorogenic acids inhibit key enzymes linked to type 2 diabetes (in vitro): a comparative study," Journal of Basic and Clinical Physiology and Pharmacology, vol. 26, no. 2, pp. 165-170, 2015.

[64] M. Roghani, T. Baluchnejadmojarad, and T. Baluchnejadmojarad, "Hypoglycemic and hypolipidemic effect and antioxidant activity of chronic epigallocatechingallate in streptozotocin-diabetic rats," Pathophysiology, vol. 17, no. 1, pp. 55-59, 2010. 
[65] O. O. Erejuwa, S. A. Sulaiman, and M. S. A. Wahab, "Fructose might contribute to the hypoglycemic effect of honey," Molecules, vol. 17, no. 2, pp. 1900-1915, 2012.

[66] J. Muthukumaran, S. Srinivasan, R. S. Venkatesan, V. Ramachandran, and U. Muruganathan, "Syringic acid, a novel natural phenolic acid, normalizes hyperglycemia with special reference to glycoprotein components in experimental diabetic rats," Journal of Acute Disease, vol. 2, no. 4, pp. 304-309, 2013.

[67] R. B. Kasti, S. A. Nabi, S. Swapna, and C. Apparao, "Cinnamic acid as one of the antidiabetic active principle (s) from the seeds of Syzygium alternifolium," Food and Chemical Toxicology, vol. 50, no. 5, pp. 1425-1431, 2012.

[68] H. Dong, X. Yang, J. He, S. Cai, K. Xiao, and L. Zhu, "Enhanced antioxidant activity, antibacterial activity and hypoglycemic effect of luteolin by complexation with manganese (II) and its inhibition kinetics on xanthine oxidase," RSC Advances, vol. 7, no. 84, pp. 53385-53395, 2017.

[69] L. H. Cazarolli, P. Folador, H. H. Moresco, I. M. C. Brighente, M. G. Pizzolatti, and F. R. M. B. Silva, "Mechanism of action of the stimulatory effect of apigenin-6-C- $(2$ "-O- $\alpha$-l-rhamnopyranosyl)- $\beta$-l-fucopyranoside on $14 \mathrm{C}$-glucose uptake," Chemico-Biological Interactions, vol. 179, no. 2-3, pp. 407-412, 2009.

[70] H. Jemai, A. El Feki, and S. Sayadi, "Antidiabetic and antioxidant effects of hydroxytyrosol and oleuropein from olive leaves in alloxan-diabetic rats," Journal of Agricultural and Food Chemistry, vol. 57, no. 19, pp. 8798-8804, 2009.

[71] A. A. H. Fernandes, E. L. B. Novelli, K. Okoshi et al., "Influence of rutin treatment on biochemical alterations in experimental diabetes," Biomedicine \& Pharmacotherapy, vol. 64, no. 3, pp. 214-219, 2010.

[72] S. F. Nabavi, S. M. Nabavi, S. Habtemariam et al., "Hepatoprotective effect of gallic acid isolated from Peltiphyllum peltatum against sodium fluoride-induced oxidative stress," Industrial Crops and Products, vol. 44, pp. 50-55, 2013.

[73] M. P. Solano, R. B. Goldberg, and R. B. Goldberg, "Management of dyslipidemia in diabetes," Cardiology in Review, vol. 14, no. 3, pp. 125-135, 2006.

[74] T. P. Degenhardt, "Pyridoxamine inhibits early renal disease and dyslipidemia in the streptozotocin-diabetic rat," Kidney International, vol. 61, no. 3, pp. 939-950, 2002.

[75] O. Erejuwa, N. Nwobodo, J. Akpan et al., "Nigerian honey ameliorates hyperglycemia and dyslipidemia in alloxan-induced diabetic rats," Nutrients, vol. 8, no. 3, p. 95, 2016.

[76] L. Mihardja, D. Delima, R. G. A. Massie, M. Karyana, P. Nugroho, and E. Yunir, "Prevalence of kidney dysfunction in diabetes mellitus and associated risk factors among productive age Indonesian," Journal of Diabetes and Metabolic Disorders, vol. 17, no. 1, pp. 53-61, 2018.

[77] J. M. Forbes, M. T. Coughlan, and M. E. Cooper, "Oxidative stress as a major culprit in kidney disease in diabetes," Diabetes, vol. 57, no. 6, pp. 1446-1454, 2008.

[78] B. B. Halliwell and H. E. Poulsen, "Oxidative stress," in Cigarette Smoke and Oxidative Stress, pp. 1-4, Springer, Berlin, Germany, 2006.

[79] I. C. West, "Radicals and oxidative stress in diabetes," Diabetic Medicine, vol. 17, no. 3, pp. 171-180, 2000.

[80] U. Asmat, K. Abad, and K. Ismail, "Diabetes mellitus and oxidative stress-A concise review," Saudi Pharmaceutical Journal, vol. 24, no. 5, pp. 547-553, 2016.

[81] V. Lubrano and S. Balzan, "Enzymatic antioxidant system in vascular inflammation and coronary artery disease," World Journal of Experimental Medicine, vol. 5, no. 4, p. 218, 2015.
[82] J. Mohammadi and P. R. Naik, "The histopathologic effects of Morus alba leaf extract on the pancreas of diabetic rats," Turkish Journal of Biology, vol. 36, no. 2, pp. 211-216, 2012.

[83] K. Hamden, S. Carreau, M. A. Boujbiha et al., "Hyperglycaemia, stress oxidant, liver dysfunction and histological changes in diabetic male rat pancreas and liver: protective effect of $17 \beta$-estradiol," Steroids, vol. 73 , no. 5, pp. 495-501, 2008.

[84] K. S. Balamash, H. M. Alkreathy, E. H. Al Gahdali, S. O. Khoja, and A. Ahmad, "Comparative biochemical and histopathological studies on the efficacy of metformin and virgin olive oil against streptozotocin-induced diabetes in Sprague-Dawley rats," Journal of Diabetes Research, vol. 2018, Article ID 4692197, 10 pages, 2018.

[85] R. Afroz, "Protective effect of Sundarban honey against acetaminophen-induced acute hepatonephrotoxicity in rats," Evidence-Based Complementary and Alternative Medicine, vol. 2014, Article ID 143782, 8 pages, 2014. 